\title{
Spatial distribution of the source-receptor relationship of sulfur in Northeast Asia
}

\author{
M. Kajino ${ }^{1, *}$, H. Ueda ${ }^{2}$, K. Sato ${ }^{3}$, and T. Sakurai ${ }^{4}$ \\ ${ }^{1}$ Research Center for Advanced Science and Technology, The University of Tokyo, Tokyo, Japan \\ ${ }^{2}$ Dept. of Environ. and Life Engineering, Toyohashi Institute of Technology, Toyohashi, Japan \\ ${ }^{3}$ Asia Center for Air Pollution Research, Niigata, Japan \\ ${ }^{4}$ Japan NUS Co. LTD, Tokyo, Japan \\ *now at: Meteorological Research Institute, Japan Meteorological Agency, Tsukuba, Japan
}

Received: 22 September 2010 - Published in Atmos. Chem. Phys. Discuss.: 10 December 2010

Revised: 24 June 2011 - Accepted: 30 June 2011 - Published: 7 July 2011

\begin{abstract}
The spatial distribution of the source-receptor relationship (SRR) of sulfur over Northeast Asia was examined using a chemical transport model (RAQM) off-line coupled with a meteorological model (MM5). The simulation was conducted for the entire year of 2002. The results were evaluated using monitoring data for six remote stations of the Acid Deposition Monitoring Network in East Asia (EANET). The modeled $\mathrm{SO}_{2}$ and $\mathrm{O}_{3}$ concentrations agreed well with the observations quantitatively. The modeled aerosol and wet deposition fluxes of $\mathrm{SO}_{4}^{2-}$ were underestimated by $30 \%$ and $50 \%$, respectively. The domain was divided into 5 source-receptor regions: (I) North China; (II) Central China; (III) South China; (IV) South Korea; and (V) Japan. The sulfur deposition in each receptor region amounted to about $50-75 \%$ of the emissions from the same region. The largest contribution to the deposition in each region was originated from the same region, accounting for 53-84\%. The second largest contribution was due to Region II, supplying $14-43 \%$. The spatial distributions of the SRRs revealed that subregional values varied by about two times more than regional averages due to nonuniformity across the deposition fields. Examining the spatial distributions of the deposition fields was important for identifying subregional areas where the deposition was highest within a receptor region. The horizontal distribution changed substantially according to season.
\end{abstract}

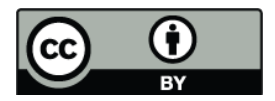

Correspondence to: M. Kajino

(kajino@mri-jma.go.jp)

\section{Introduction}

Sulfur oxides are one of the most important trace substances in the atmosphere because they cause environmental acidification and aerosol-induced climate changes. The East Asian region has been one of the largest emission source regions in the world (Streets et al., 2003; Ohara et al., 2007; Zhang et al., 2009). Since $\mathrm{SO}_{2}$ emitted from anthropogenic sources and volcanic eruptions is oxidized in the atmosphere during long-range transport and forms $\mathrm{SO}_{4}^{2-}$, which causes acidification of soil, land, water, and vegetation, the issue of transboundary air pollution evokes significant scientific interest and political concern (Carmichael et al., 2002). To better understand the trans-boundary problem and plan environmental policies, inter-political or inter-regional source-receptor relationship (SRR) analyses have been widely conducted (e.g., Carmichael et al., 2002; Lin et al., 2008; Nagashima et al., 2010). State-of-the-art techniques have been established to study SRRs of substances with highly non-linear photochemical chain reactions, such as those of $\mathrm{NO}_{\mathrm{y}}$ (Lin et al., 2008) and $\mathrm{O}_{3}$ (Nagashima et al., 2010), and knowledge of SRRs in Asian regions has been accumulating (Lin et al., 2008).

For the accurate and reliable estimation of an SRR between regions and to plan the most effective strategy for environmental policies, the development of accurate emissions inventories, the formulation of sophisticated elementary processes in three-dimensional chemical transport models, and the extensive and long-term monitoring of air pollutants using accurate instruments are required. In order to reduce uncertainties and to better estimate the impact of

Published by Copernicus Publications on behalf of the European Geosciences Union. 
trans-boundary air pollution problems, the importance of the ensemble technique, which incorporates several chemical transport models with various implementations and formulations, has been pointed out in various model intercomparison studies, such as MICS-Asia phase I (Carmichael et al., 2002), MICS-Asia phase II (Carmichael et al., 2008), the joint research on Long-range Trans-boundary Air Pollutants in Northeast Asia (LTP project) of the Tripartite Environment Ministers Meeting among Japan, China and Korea (TEMM) (Choi et al., 2001; Kim et al., 2011).

Discussions of SRR analyses have usually been based on source-receptor tables showing the contributions of the sum of emissions in source regions relative to the aerial summation of deposition in receptor regions. However, due to the high nonuniformity of spatial distributions of deposition, spatial distributions of SRRs should be discussed together with SRR tables. Without discussions of spatial heterogeneity, we cannot identify the true contributions to deposition in some specific subregional areas. The SRR over the ocean was poorly addressed in the previous studies but informative for the budget study. Showing SRR over the ocean is especially important for persistent and bioaccumulate hazardous materials such as polycyclic aromatic hydrocarbons (PAHs), having acute and chronic toxicity to marine life (Livingstone, 1998; Hylland, 2006; Suzuki et al., 2009).

Therefore, we present the horizontal distribution of the SRR of sulfur both over the land and the ocean in Northeast Asia as well as SRR tables using a three-dimensional chemical transport model, the Regional Air Quality Model (RAQM; An et al., 2002; Han, 2007). The RAQM model was developed in the Asian Center for Air Pollution research (ACAP), formerly the Acid Deposition and Oxidant Research Center (ADORC), the network center of the Acid Deposition Monitoring Network Center in East Asia (EANET). The model has been used for various air pollution studies and substantial modifications have been made based on comparison and evaluation with extensive and longterm monitoring data in the Asian region (An et al., 2002, 2003; Han et al., 2004, 2005, 2006, Kajino et al., 2004, 2005; Han, 2007; Han et al., 2008). The model has been used in the MICS-Asia Phase II study (Carmichael et al., 2008) and the LTP project (Choi et al., 2001). Verification of the simulation used in this study was made by Kim et al. (2011) by comparing the model results with observation data from the LTP stations and the results of the other LTP model participants. In this paper, the model results are also compared with EANET observation data. The model formulation and the SRR analysis method are described in Sect. 2. The model results are evaluated using the EANET monitoring data for the concentrations and deposition amounts of air pollutants in Sect. 3, and the spatial and seasonal variations of concentrations, deposition amounts, and SRRs of sulfur compounds are discussed in Sect. 4. Major findings are summarized in Sect. 5.

\section{Methods}

\subsection{Off-line coupled meteorology-chemical transport model system}

A three-dimensional Eulerian model, the Regional Air Quality Model (RAQM; An et al., 2002; Han, 2007), which is built on a spherical and terrain-following coordinate system, was used. The model includes a series of major processes for chemical species that are found in the troposphere, such as advection, diffusion, dry deposition, multi-phase chemistry, cloud mixing, and scavenging. A simple but accurate mass conservative advection algorithm is applied to solve the mass conservation equation with a time-splitting technique (Walcek and Aleksic, 1998; Carmichael et al., 1991). The vertical eddy diffusivity is parameterized according to the approach of Byun and Dennis (1995), which has been used in the Regional Acid Deposition Model (RADM 2.6). The dry deposition module for gases is calculated by a modified Wesely's parameterization scheme (Walmsley and Wesely, 1996). For sulfate, the dry deposition velocity is parameterized according to the work of Walcek et al. (1986). Gas phase chemistry can be represented by either a condensed mechanism developed (He and Huang, 1996; An et al., 2002; Han et al., 2006) on the basis of Atkinson et al. (1982) or a complete version of the CB-IV mechanism (Gery et al., 1989), with an updated isoprene mechanism. The model ISSOROPIA1.7 (http://nenes.eas.gatech. edu/ISORROPIA/; Nenes et al., 1998) is incorporated into RAQM and applied to account for the partition or transformation between gas and aerosol phases. The photolysis rate is currently calculated according to Madronich (1987), with the effects of clouds and aerosols taken into account. Cloud information such as cloud top, cloud base, liquid water content, and cloud fraction are diagnosed using the same method as that used in Chang et al. (1987), as described below. Clouds play an important role in chemical transformation and removal of trace species, especially for sulfur, and thus the cloud process modeling of RAQM is described a little more in detail. The cloud process submodel used in RAQM is based on RADM (Chang et al., 1987) so one could find a full description in their paper. Each representative cloud in a grid has a depth and fractional area of coverage determined by the grid-scale environmental parameters. A one-dimensional diagnostic cloud model is used to specify vertical distributions of several cloud dynamical and microphysical properties such as cloud fraction, cloud base, cloud top, and condensed water content. To determine the properties, three sets of diagnostic equations are applied for the three respective cloud types, precipitating cumuliform clouds, precipitation stratiform clouds, and fair weather cloudiness. Rainout of aerosols, dissolutions of soluble and reactive gases, and chemical reactions in a cloud are computed using a box aqueous chemical and scavenging submodel. $\mathrm{SO}_{2}$ dissolved into water droplets is oxidized 


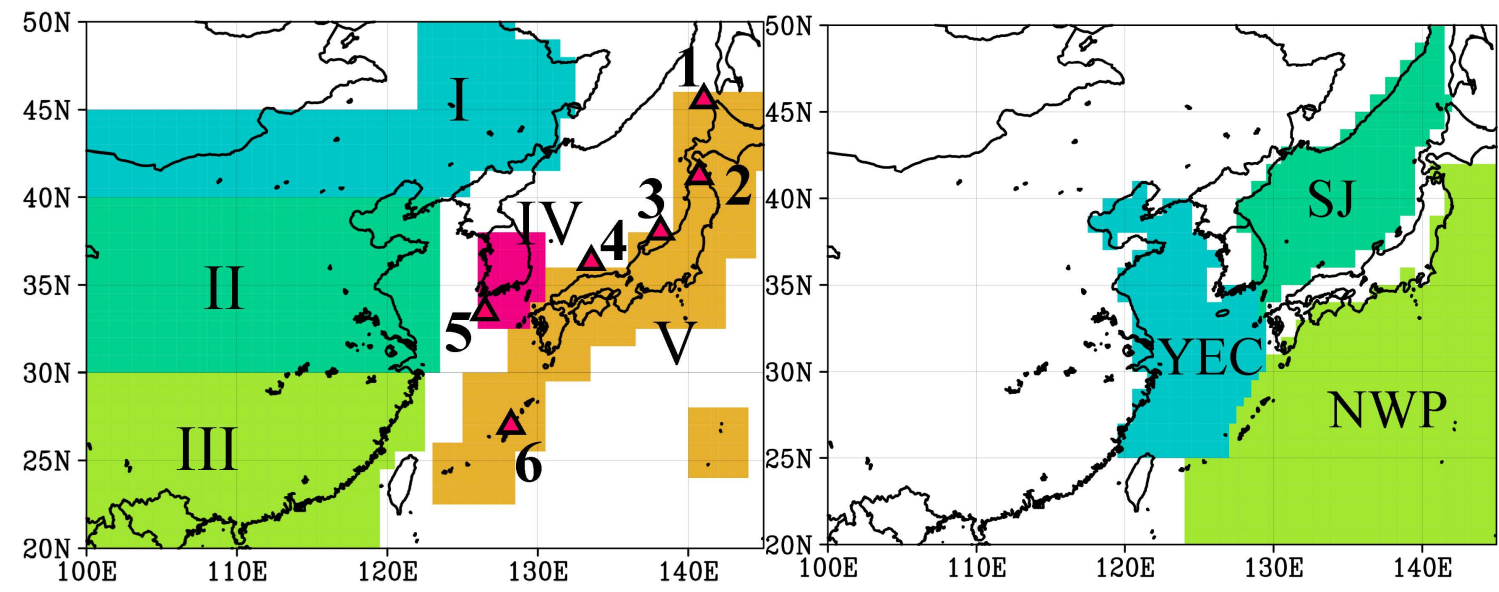

Fig. 1. The model domain and the EANET remote monitoring stations (1-6, pink triangle): 1. Rishiri, 2. Tappi, 3. Sado, 4. Oki, 5. Jeju, and 6. Hedo. Descriptions of the locations are given in Table 1. The color shaded areas (left) I to V represent regions for source-receptor relationship analyses, I: North China $\left(>40^{\circ} \mathrm{N}\right)$, II: Central China $\left(>30^{\circ} \mathrm{N},<40^{\circ} \mathrm{N}\right)$, III: South China $\left(<30^{\circ} \mathrm{N}\right)$, IV: South Korea, and V: Japan. The areas on the right represent oceanic receptor areas, YEC: Yellow Sea and East China Sea, SJ: Sea of Japan, and NWP: Northwest Pacific Ocean.

by $\mathrm{H}_{2} \mathrm{O}_{2}, \mathrm{O}_{3}$, methyl hydrogen peroxide, peroxyacetic acid, and trace metals $\left(\mathrm{Fe}^{3+}\right.$ and $\left.\mathrm{Mn}^{2+}\right)$. Accumulated wet deposition from precipitating clouds is computed by integrating the product of the grid-averaged precipitation rate and mean cloud water composition during each cloud lifetime. It should be noted here that the precipitation rate predicted by MM5 and by this submodel are independent.

The MM5 (Grell et al., 1994) version 3.7 (FifthGeneration NCAR/Penn State Mesoscale Model) was used to provide meteorological fields for RAQM (wind, temperature, water mixing ratio, and surface variables). The NCEP FNL reanalysis data with a 1.0-degree resolution was used to provide the initial and boundary conditions for meteorological fields. Four-dimensional data assimilation (nudging by three-dimensional reanalysis data) was utilized to improve model results, especially for the wind and temperature fields. Specific physical options, such as the MRF scheme (Hong and Pan, 1996) for PBL, Betts-Miller (Betts, 1986; Betts and Miller, 1986, 1993) for cumulus, RRTM for radiation, mixed-phase for explicit moisture, and fivelayer soil model for land-air processes, were chosen for the simulations. The domain for MM5 was larger than that of RAQM, with the center located at $35^{\circ} \mathrm{N}, 125^{\circ} \mathrm{E}$. There were $125 \times 95$ grid numbers in a plane with a $45-\mathrm{km}$ grid resolution, and 23 sigma layers from the surface to $100 \mathrm{hPa}$. The MM5 output was adequately interpolated from a Lambert projection to the spherical coordinates of RAQM.

\subsection{Parameters used in the simulation}

A simulation was performed for the year 2002, from 1 January to 31 December, with a spin-up period of 3 days. A 3-day spin-up period is usually insufficient for longer-lived secondary components such as $\mathrm{O}_{3}$ and aerosols. However, as the integration period of the simulation was the one year, the initialization problem may not be serious for the whole simulation results. March, July, and December were selected for the assessment of seasonality because they represent spring, summer, and winter, respectively. The model domain covered Northeast Asia $\left(100-145^{\circ} \mathrm{E}, 20-50^{\circ} \mathrm{N}\right)$ with a horizontal resolution of 0.5 degrees (thus, $90 \times 60$ grids, Fig. 1). In RAQM, 12 layers stretched vertically from the surface to $10 \mathrm{~km}$ (at about 50, 150, 300, 500, 750, 1500, $2500,3500,4500,6000,7500$, and $8950 \mathrm{~m}$ ). The initial and boundary conditions were taken as the lower end of observations available from recent studies for East Asia (Carmichael et al., 1998; Luo et al., 2000). Side boundary conditions were held during the simulation, whereas the top boundary condition for $\mathrm{O}_{3}$ was implemented as a constant level with seasonal variation. Topography data were obtained from the US Geological Survey Earth Resources Observation System (EROS) Data Center. The land use data came from DeFries and Townshend (1994), in which 12 categories of land use are classified.

Emission inventories of $\mathrm{SO}_{2}, \mathrm{NO}_{\mathrm{x}}, \mathrm{CO}, \mathrm{NH}_{3}$, and volatile organic compounds (VOCs) were derived from the common dataset used in the LTP project (Choi et al., 2001; Kim et al., 2011). The base year of the emission inventory is same as the simulation period, the year 2002. LTP is one of the joint research projects under the Tripartite Envirionment Ministers Meeting among Korea, China and Japan (TEMM), which aims to understand the state of air quality in Northeast Asia, laying a foundation for research on long-range transports, to develop the scientific basis for environmental decision-making, and ultimately to improve air quality in Northeast Asia. In this context, we focused mainly on 
environmental impacts of anthropogenic emissions from the three huge-emitter countries over the Northeast Asian subregion. The emission from other Asian regions such as South Asian and Southeast Asian countries are not included in the emission inventory. The emission data were available in a grid of 1 degree $\times 1$ degree and equally allocated to a $0.5^{\circ}$ model grid for RAQM. Biogenic VOCs over China, including isoprene, monoterpenes, and other VOCs, were taken into account. Monthly values of biogenic VOC emissions were obtained for model simulations by multiplying annual amounts by temporal scaling factors. All area sources were assigned to the lowest model layer, about $50 \mathrm{~m}$ above the ground. In addition to the LTP standard emissions data, volcanic emissions were included from MICS-Asia emissions data (Carmichael et al., 2008), with a release height at an altitudinal range of 750-1500 m. In particular, Mt. Oyama in Miyakejima Island $\left(139.531^{\circ} \mathrm{E}, 34.081^{\circ} \mathrm{N}, 813 \mathrm{~m}\right.$ a.s.l.) has a high level of $\mathrm{SO}_{2}$ emissions that have resulted in substantial environmental acidification in Far East Asia (Satsumabayashi et al., 2004, Kajino et al., 2004, 2005). Mt. Oyama is located in the northwest Pacific Ocean, $180 \mathrm{~km}$ south of the Tokyo metropolitan area, and it began to erupt on 8 July 2000. The Seismological and Volcanological Department of the Japan Meteorological Agency (SVD-JMA) has collected continuous measurements of the $\mathrm{SO}_{2}$ emissions and smoke height above the crater since September 2000 (Kazahaya, 2001). It was reported that the daily amount of $\mathrm{SO}_{2}$ emissions from Mt. Oyama in 2002 was approximately 9500 tons day ${ }^{-1}$ on average. $\mathrm{SO}_{2}$ from shipping and biogenic sulfur compounds such as dimethyl sulfide (DMS), dimethyl disulfide (DMDS), $\mathrm{COS}, \mathrm{H}_{2} \mathrm{~S}, \mathrm{CS}_{2}$ and $\mathrm{CH}_{3} \mathrm{SH}$ from ocean surfaces were not considered in the study. The contribution of emission fluxes of those species to concentrations and depositions of $\mathrm{SO}_{2}$ and sulfate over the region could be much smaller compared to anthropogenic $\mathrm{SO}_{2}$ from China and that from Miyakejima volcano (Streets et al., 2003; Kajino et al., 2004). However, those can be a reason for the discrepancy between the simulation and the observation because the observation sites we selected are located at isolated islands or capes, surrounded by ocean.

\subsection{Source-receptor relationship method}

Source-receptor relationships (SRR) were calculated using the following formula:

$$
R_{i j}(\%)=\frac{H_{i j}}{\sum_{1=1}^{n} H_{i j}} \times 100,
$$

where $R_{i j}$ is the contribution of $i$-th emission source to the $j$ th receptor and $H_{i j}$ is the deposition amount at the $j$-th receptor due to the $i$-th source. Contributions from the respective emission sources were obtained from the difference between the result when considering all of the emission sources and the result when the $i$-th source was excluded. This method is simple but useful for compounds involving less non-linearity in their photochemical chain reactions, such as sulfur compounds. In this study, the domain was divided into five source-receptor regions (Fig. 1).

In recent works, to derive the SRR, emissions of precursors are reduced by $15 \%$ and the simulation results were scaled up to represent the entire emission from an emitter (Nyiri et al., 2010). The method was found to be more robust as the full removal of the source input caused non-linearity effects on SRR for highly reactive nitrogen compounds and $\mathrm{O}_{3}$ through the photochemical chain reactions. Still the problem is usually of minor importance when sulfur compounds are considered, and thus we utilized Eq. (1).

\subsection{EANET observation}

We used the Acid Deposition Monitoring Network in East Asia (EANET) monitoring data (EANET, Guidelines for acid deposition monitoring in East Asia, available at http://www. eanet.cc/product.html) for model evaluation. The EANET stations monitor 1-day accumulated once per week (Korea) or 14-day (Japan) accumulated concentrations of gaseous species $\left(\mathrm{HNO}_{3}, \mathrm{HCl}, \mathrm{NH}_{3}\right.$, and $\left.\mathrm{SO}_{2}\right)$ and aerosol components $\left(\mathrm{SO}_{4}^{2-}, \mathrm{NO}_{3}^{-}, \mathrm{Cl}^{-} \mathrm{NH}_{4}^{+}, \mathrm{Na}^{+}, \mathrm{Mg}^{2+}, \mathrm{K}^{+}\right.$, and $\mathrm{Ca}^{2+}$ ) using the filter pack (FP) method (EANET, Technical documents for filter pack method in East Asia, available at http://www.eanet.cc/product.html). They monitor daily accumulated concentrations in precipitation $\left(\mathrm{SO}_{4}^{2-}, \mathrm{NO}_{3}^{-}, \mathrm{Cl}^{-}\right.$ $\mathrm{NH}_{4}^{+}, \mathrm{Na}^{+}, \mathrm{Mg}^{2+}, \mathrm{K}^{+}$, and $\mathrm{Ca}^{2+}$ ) using precipitation collection and ion chromatography analysis (EANET, Technical manual for wet deposition monitoring in East Asia, available at http://www.eanet.cc/product.html) and hourly $\mathrm{SO}_{2}, \mathrm{NO}$, $\mathrm{NO}_{2}, \mathrm{NO}_{\mathrm{x}}, \mathrm{O}_{3}, \mathrm{PM}_{2.5}$, and $\mathrm{PM}_{10}$ concentrations and meteorological data such as wind speed, wind direction, temperature, relative humidity and solar radiation. Quality assurance and quality control (QA/QC) activities are conducted to ensure high quality of monitoring data according to the QA/QC program guidelines (available at http://www.eanet. cc/product.html). The FP method is associated with several distinct artifact problems during the long-term sampling period. However, the effects can be neglected in this study because we focus only on sulfur compounds that are not affected significantly compared to other semi-volatile components, such as ammonium, nitrate and chloride.

To deduce the anthropogenic and volcanic $\mathrm{SO}_{4}^{2-}$, nonseasalt (nss)- $\mathrm{SO}_{4}^{2-}$ are defined, excluding the contribution of seasalt originated proportions as follows:

$\left[\right.$ nss-SO $\left.{ }_{4}^{2-}\right]=\left[\mathrm{SO}_{4}^{2-}\right]-0.251 \times\left[\mathrm{Na}^{+}\right]$

where [ ] denote atmospheric weight concentrations in $\mu \mathrm{g} \mathrm{m}^{-3}$.

Six remote stations located on small islands or isolated capes, depicted in Fig. 1 and listed in Table 1, were selected for comparison with simulation results for model evaluation. These stations were selected because without nearby huge 
Table 1. Description of the EANET remote observation sites used in this study. Each station is depicted in Fig. 1.

\begin{tabular}{lccrl}
\hline & $\begin{array}{c}\text { Longitude } \\
(\mathrm{E})\end{array}$ & $\begin{array}{c}\text { Latitude } \\
(\mathrm{N})\end{array}$ & $\begin{array}{r}\text { Altitude } \\
(\mathrm{m} \text { a.s.l. })\end{array}$ & Country \\
\hline 1. Rishiri & $141^{\circ} 12^{\prime}$ & $45^{\circ} 07^{\prime}$ & 40 & Japan \\
2. Tappi & $120^{\circ} 21^{\prime}$ & $41^{\circ} 15^{\prime}$ & 105 & Japan \\
3. Sado & $138^{\circ} 24^{\prime}$ & $38^{\circ} 14^{\prime}$ & 136 & Japan \\
4. Oki & $133^{\circ} 11^{\prime}$ & $36^{\circ} 17^{\prime}$ & 90 & Japan \\
5. Jeju & $126^{\circ} 10^{\prime}$ & $33^{\circ} 18^{\prime}$ & 72 & Korea \\
6. Hedo & $127^{\circ} 15^{\prime}$ & $26^{\circ} 52^{\prime}$ & 60 & Japan \\
\hline
\end{tabular}

emission sources and complexity of local orographically induced winds, air pollutant transport events mostly coincide with synoptic-scale disturbances and are generally well reproduced by regional-scale models.

\section{Model evaluation using the EANET monitoring data}

The RAQM model performance has been extensively evaluated by comparing to EANET monitoring data sets in previous studies. The model could reproduce monthly $\mathrm{NO}_{3}^{-}$ concentrations in rainwater (An et al., 2002), hourly $\mathrm{SO}_{2}$ and monthly nss- $\mathrm{SO}_{4}^{2-}$ concentrations in rainwater affected by the Miyakejima Volcano (An et al., 2003; Kajino et al., 2004), $\mathrm{PM}_{2.5}, \mathrm{PM}_{10}$, and the aerosol size distribution during dust events (Han et al., 2004), 3-hourly concentrations of aerosol nss- $\mathrm{SO}_{4}^{2-}$ and $\mathrm{NH}_{4}^{+}$(Kajino et al., 2004), hourly concentrations of $\mathrm{SO}_{2}, \mathrm{NO}_{\mathrm{x}}$, and $\mathrm{O}_{3}$ (Kajino et al., 2005; $\mathrm{Han}$ et al., 2004, 2006), wet deposition of nss- $\mathrm{SO}_{4}^{2-}, \mathrm{NO}_{3}^{-}$, $\mathrm{NH}_{4}^{+}, \mathrm{Ca}^{2+}, \mathrm{H}^{+}$(Han et al., 2006), $\mathrm{O}_{3}$ relevant trace species such as $\mathrm{NO}_{\mathrm{x}}$ and VOCs measured for the TRACE-P project (Han, 2007), and all of those species along with a model inter-comparison study for MICS-Asia Phase II (Carmichael et al., 2008; Han et al., 2008 and references therein).

Table 2 summarizes statistical analyses for comparisons between daily and monthly observations and simulation data at the six EANET remote monitoring stations depicted in Fig. 1 and described in Table 1. The $\mathrm{SO}_{2}$ and $\mathrm{O}_{3}$ concentrations and wet deposition of nss- $\mathrm{SO}_{4}^{2-}$ were measured at all of the stations, whereas aerosol nss- $\mathrm{SO}_{4}^{2-}$ was measured at Jeju (1 day per week for the entire year), Oki (14 days in July 2002) and Rishiri (14 days in March 2002). The filter pack measurements were not yet started at the other stations during the period examined. The table shows the medians and averages of the observations and simulation data, the mean bias (MB) of simulations compared to observations, the root mean square errors (RMSEs), the correlation coefficients (Rs), and the FAC2s (number fraction of data which satisfy that the simulation and observation agree within a factor of 2) between simulations and observations.
Table 3 summarizes the emission amounts accumulated over the region for the emission inventory used in the study. Because the Asian region is one of the most serious emission source regions of atmospheric pollutants in the world, there have been various studies for the estimation of its emission inventory. For recent years, Streets et al. (2003), for the base year 2000, Ohara et al. (2007), for up to 2003, and Zhang et al. (2009), for the base year 2006, have frequently been used and widely credited. The estimated Chinese emission from our emission inventory was $20.7 \mathrm{Tg} \mathrm{SO}$, which is comparable to Streets' inventory $\left(20.4 \mathrm{Tg} \mathrm{SO}_{2}\right)$ and relatively smaller than the newer estimates from Ohara's inventory $\left(27.6 \mathrm{Tg} \mathrm{SO}_{2}\right)$ and Zhang's inventory $\left(22.9 \mathrm{Tg} \mathrm{SO}_{2}\right.$ for 2001).

In Table 2, the simulated $\mathrm{SO}_{2}$ concentrations agree with observations quantitatively (median and average), whereas the correlation among them is not large. It is mainly due to the higher detection limit of $\mathrm{SO}_{2}(0.1 \mathrm{ppbv})$ compared with concentrations measured at the stations $(\sim 0.3 \mathrm{ppb})$. The coarse horizontal resolution of our emission inventory ( 1 degree) might cause the relatively small correlation coefficients. It is coarser than other inventories and the model grid resolution ( 0.5 degrees). However, it may not be critical because we have selected only remote stations, where we solely capture long-range transport phenomena. The distances between the monitoring stations and the huge emission source regions (the Asian continent) are $\sim 1000 \mathrm{~km}$. Big transport events usually last on the scale of several hours, shorter than 1 day. Though the daily based correlation coefficient is not very large, on an hourly basis, the measured and modeled high concentration peaks are observed to coincide in general. Taken together with the fact that the daily and monthly mean values are reasonable, the simulation performed successfully.

Trends of simulated $\mathrm{O}_{3}$ concentrations were generally well reproduced ( $R=0.4$ to 0.5 and FAC2 $>0.9)$, whereas the mean concentration was lower by $10 \mathrm{ppb}$. Due to the complexity of $\mathrm{O}_{3}$ photochemistry and its relatively long lifetime, the regional scale simulation of $\mathrm{O}_{3}$ is difficult compared with other primary species. It depends highly on the concentrations and speciation of VOCs and on lateral and upper boundary concentrations of the model domain regions, both of which are very much uncertain. Since hourly variations for $\mathrm{NO}_{\mathrm{x}}$ and VOC emissions were not provided in the inventories we used, the variations were not considered for the simulation. This might cause the poor model performance for ozone. Still, as long as sulfur compounds are concerned, this level of deviations in $\mathrm{O}_{3}(R \sim 0.5$ and FAC2 $>0.9)$ will not affect substantially on predicting conversion rates of S(IV) to $\mathrm{S}(\mathrm{VI})$ in the air as well as in water droplets. To predict highly reactive $\mathrm{O}_{3}$ and nitrogen compounds, hourly variations in emissions should be carefully taken into account.

Trends in the simulated monthly mean concentration of aerosol nss- $\mathrm{SO}_{4}^{2-}$ agreed well with the observations $(R=0.80)$. However, the median and mean values were substantially underestimated by about $30 \%$. Atmospheric $\mathrm{SO}_{2}$ 
Table 2. Statistical analysis for comparisons between daily and monthly observations and simulation data at the six EANET remote stations.

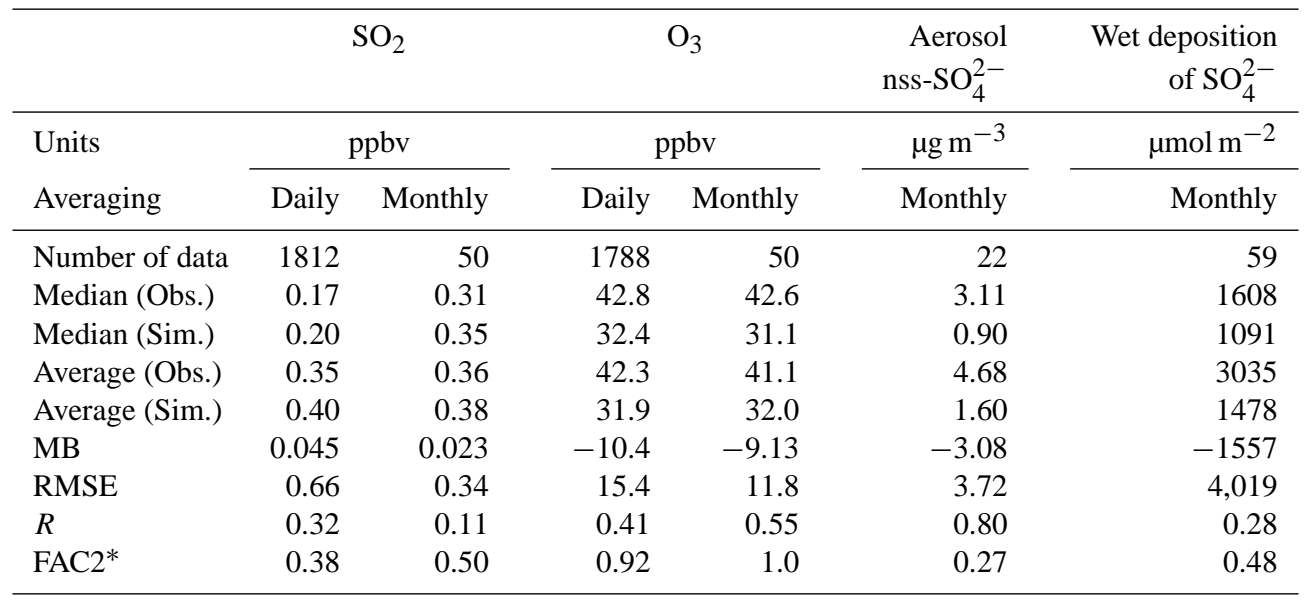

* Number fraction of data within a factor of two.

Table 3. Emissions of sulfur (kton $\left.\mathrm{S} \mathrm{yr}^{-1}\right)$.

\begin{tabular}{lcccccc}
\hline Region & I & II & III & IV & V & $\begin{array}{c}\text { Miyakejima } \\
\text { Volcano* }\end{array}$ \\
\hline Emissions & 1007.4 & 6019.32 & 3302.4 & 557.6 & 454.7 & 1734.1 \\
\hline
\end{tabular}

* Miyakejima volcanic emissions are included in Region V for SRR analyses.

is dissolved efficiently into cloud and rain droplets with fast oxidation occurring in the aqueous phase. Some of the nss$\mathrm{SO}_{4}^{2-}$ produced in hydrometeors may remain in the atmosphere after the evaporation of clouds and some may be deposited to the ground surface by precipitation. The high uncertainty in the heterogeneous oxidation and wet scavenging processes contribute to either an increase or a decrease in particulate nss- $\mathrm{SO}_{4}^{2-}$ concentrations. Heterogeneous nss- $\mathrm{SO}_{4}^{2-}$ production on sea-salt (Chameides and Stelson, 1992) and dust (Tang et al., 2004) particles should promote the oxidation of sulfur, but these processes are missing in the model. As we focused on SRR of sulfur among the three Northeast Asian countries, the contributions of boundary conditions, which were not seriously taken into account, could be a reason for the underestimation of the modeled nss- $\mathrm{SO}_{4}^{2-}$. For the rapid growth in power production and industry in this part of the world, our initial and boundary conditions obtained from Carmichael et al. (1998) and Luo et al. (2000) could be outdated for the simulation of the year 2002. Besides, emissions from South and Southeast Asian countries were not included in the study. As the plume from outside the domain was transported in longer distances, S(IV) could be sufficiently oxidized to S(VI). This is consistent with the fact that modeled S(VI) was underestimated, whereas S(IV) was reasonable.

The simulated monthly wet deposition flux of nss$\mathrm{SO}_{4}^{2-}$ was compared with observations. The modeled wet deposition of nss- $\mathrm{SO}_{4}^{2-}$ generally underestimated the flux by about $50 \%$, with some exceptions that were overestimations. As a result, the correlation coefficient $(R)$ between the modeled and observed data was low (0.29). The underestimations of modeled nss- $\mathrm{SO}_{4}^{2-}$ in the atmosphere $\left(\mu \mathrm{g} \mathrm{m}^{-3}\right)$ and its wet deposition amount $\left(\mu \mathrm{mol} \mathrm{m}{ }^{-2}\right)$ are similar to each other. We found that the underestimation of the modeled production rate for $\mathrm{S}(\mathrm{IV})$ to $\mathrm{S}(\mathrm{VI})$ and/or the underestimation of the boundary concentrations of sulfur is a main cause for the quantitative discrepancy, whereas the modeled wet scavenging rate is reasonable. At the current stage, however, it is very difficult to identify the reasons for all of the discrepancies because all of the uncertainties in emissions, boundary conditions, gas-phase and aqueous-phase oxidation rates, the dry deposition velocity, and the wet scavenging ratio can together contribute to substantial increases and decreases in the model results. Wang et al. (2008) showed the variations in predictions of wet deposition amounts of sulfate, nitrate and ammonium by the 8 different models participated to the MICS-Asia Phase II study. They showed those varied substantially even for sulfate by factor of $>10$. Even though the emission flux of sulfur could be accurately derived, wet deposition of sulfur would be varied substantially among the current chemical transport models. However, it is still essential to evaluate and show the discrepancies in these variables because a discussion of the discrepancies is directly transferable to the uncertainty and reliability of the main topic of 

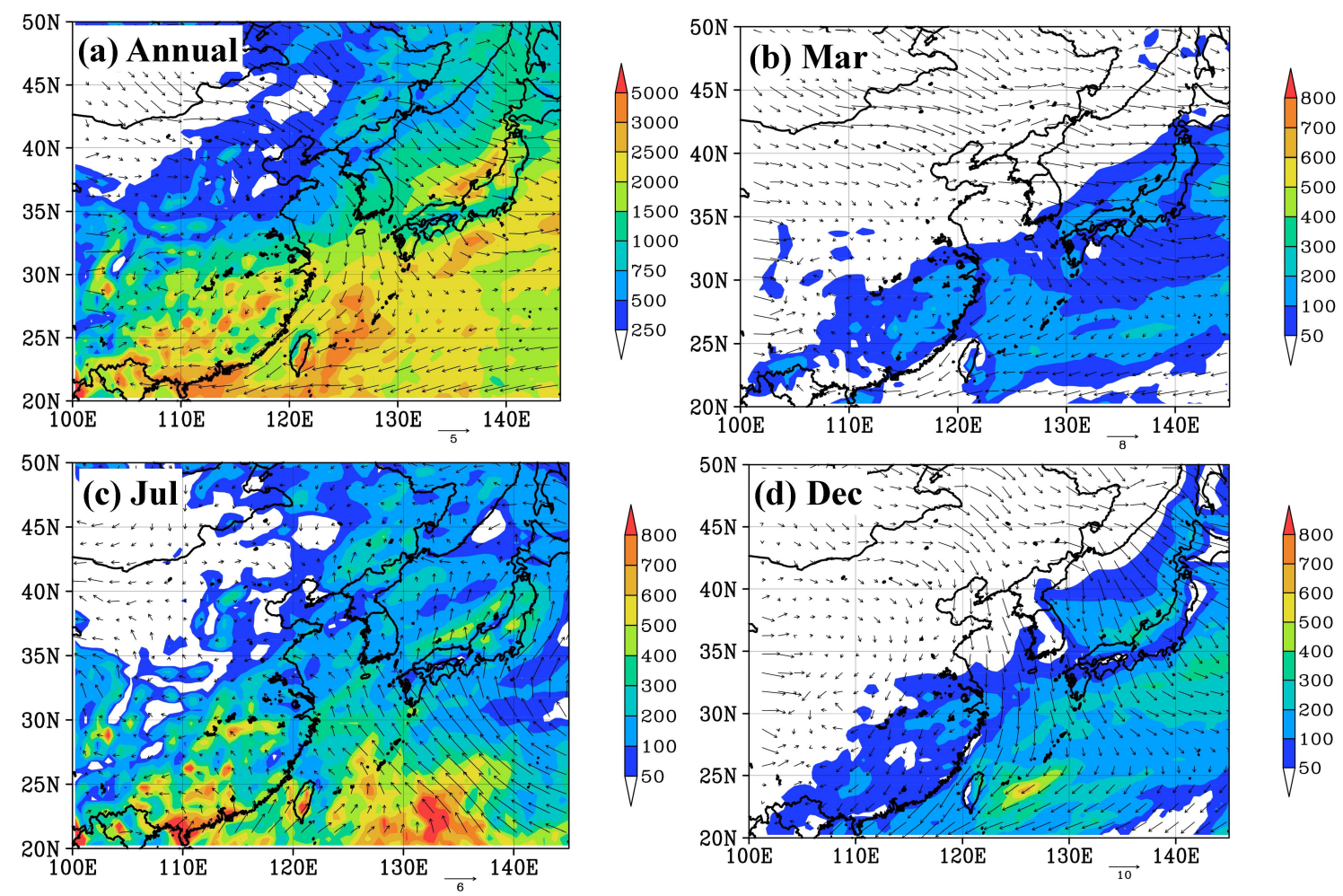

Fig. 2. Spatial distributions of (a) yearly and (b-d) monthly accumulated precipitation (mm) and mean surface wind field (m $\mathrm{s}^{-1}$ ). The selected months, (b) March, (c) July, and (d) December, represent the spring, summer, and winter seasons, respectively.

this paper, the source-receptor relationship of sulfur and its horizontal and seasonal distribution.

\section{Results and discussion}

\subsection{Annual mean and seasonal trends in surface meteorology over Northeast Asia}

Figure 2a illustrates the mean annual surface wind field and accumulated precipitation for 2002. China, Korea, and Japan are located over the baroclinic zone in the mid-latitudes, where the temperature gradient is steep and synoptic disturbances are active as a driving force of transboundary air pollution. Throughout the year, northerly to northwesterly wind was prevailing over the Yellow Sea and the Sea of Japan. The contribution of those winds to transboundary air pollution in northeast Asia was substantial. Large amounts of precipitation were observed in the southern areas of the domain, and those areas are mostly distributed in the Pacific Ocean. Inland areas of heavy local precipitation are located in the southern part of China (Region III). The precipitation was due to local cumulus convection and mostly happened in summer (June and July). Orographically forced local heavy precipitation near the coastal regions can be seen along the northern and northeastern coast of the Japanese main island and the eastern coast of Taiwan.

Figure $2 b-d$ illustrates the spatial distributions of the monthly mean surface wind fields and accumulated precipitation for (b) March, (c) July, and (d) December, which were selected to assess seasonality over the northeastern Asian regions in the spring, summer, and winter, respectively. The features in autumn are not discussed throughout the paper because they are similar to those in spring. In spring (March), shown in Fig. 2b, westerly and northwesterly winds prevailed in the northern part of the domain over both the continent and the ocean. In contrast, easterly trade winds prevailed in the subtropical regions. Wind is weak in the central and southern part of China. In summer (July), shown in Fig. 2c, southerly and southeasterly winds prevailed over the Pacific Ocean due to the Pacific high pressure system (Pacific High). Transport due to the mid-latitude westerlies in the boundary layers was not very influential in the summer season. Heavy precipitation due to local cumulus convection may substantially affect the wet deposition of air pollutants in the southern part of the region. Precipitation was large only over the northern part of the Asian continent, the Yellow Sea, and the Sea of Japan in summer. In winter (December), shown in Fig. 2d, northerly monsoons are predominant over the Yellow Sea, the East China Sea, and the Sea of Japan. Northerly winds also prevailed over the continent. 

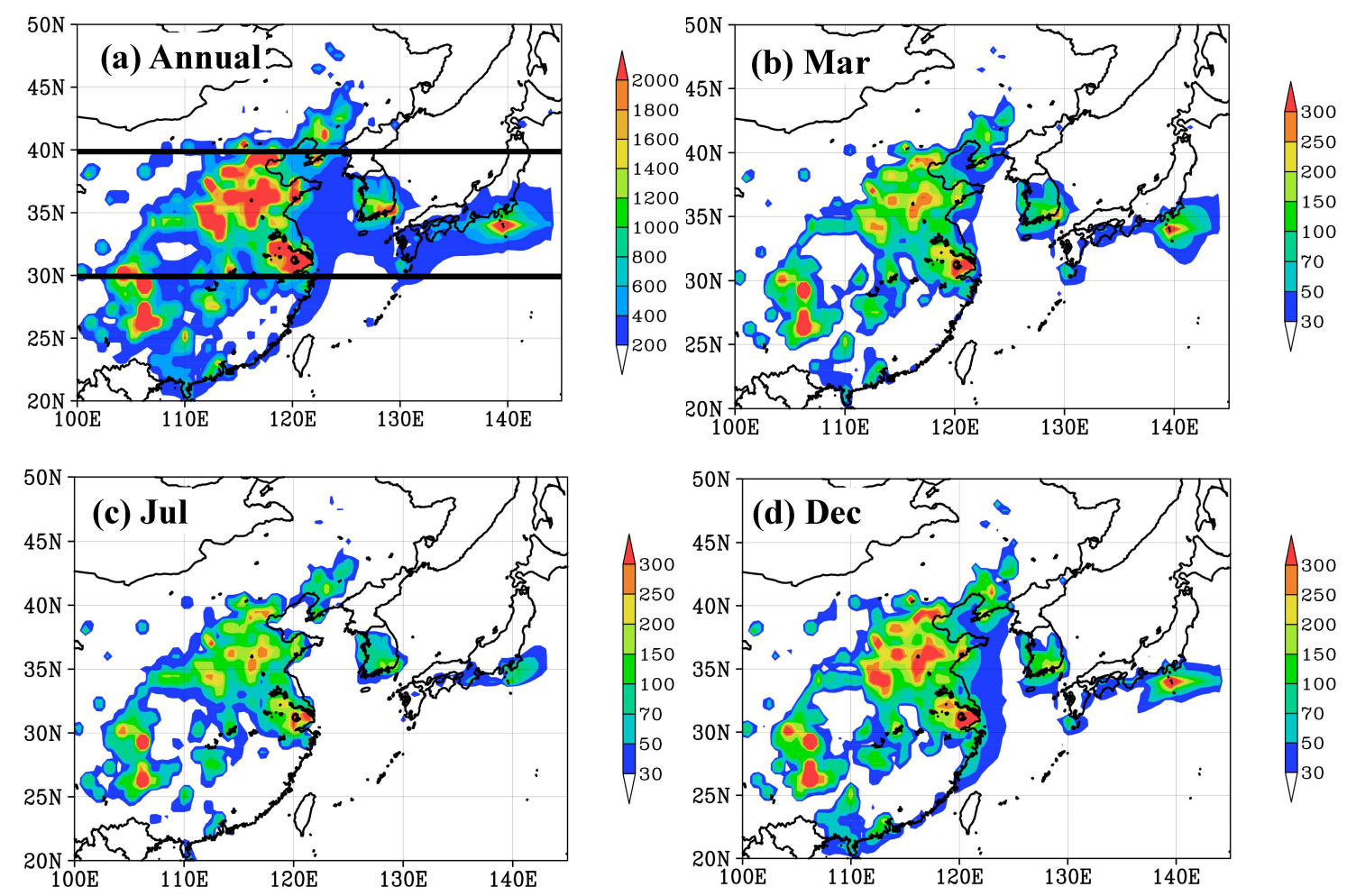

Fig. 3. Spatial distributions of (a) annual and (b-d) monthly accumulated dry deposition of total S ( $\mathrm{mg} \mathrm{S} \mathrm{m}^{-2}$ ). The solid lines in (a) indicate $40^{\circ} \mathrm{N}$ and $30^{\circ} \mathrm{N}$, the borders between Regions I and II and between Regions II and III, respectively.

\subsection{Annual mean and seasonal trends of surface concentrations and deposition of sulfur oxides}

Figure 3 illustrates the (a) annual and (b-d) monthly accumulated dry deposition of total $\mathrm{S}\left(\mathrm{mg} \mathrm{S} \mathrm{m}^{-2}\right)$. Among dry deposition of $\mathrm{S}\left(\mathrm{SO}_{2}\right.$ and aerosol $\left.\mathrm{SO}_{4}^{2-}\right), \mathrm{SO}_{2}$ was predominant and contributed more than $80 \%$ over most of the regions such as the North China Plain, the Yangtze Plain, urbanized places in Korea and Japan, the Yellow Sea, the East China Sea, and the Sea of Japan. The contribution becomes smaller over further downwind regions or regions with heavy precipitation, such as the northwest Pacific ocean (40-80\%), the northern coastal region of the Japanese main island (30-50\%), and the southern part of China (30-50\%), but the deposition amount of total $\mathrm{S}$ is much smaller ( $<200 \mathrm{mg} \mathrm{S} \mathrm{m}^{-2}$ annually) in those regions compared to that in the urbanized regions. Thus, the spatial distribution of total dry $\mathrm{S}$ deposition reflects those for the dry deposition of $\mathrm{SO}_{2}$ and surface concentrations of $\mathrm{SO}_{2}$.

In Sect. 3, it is discussed that modeled $\mathrm{SO}_{2}$ concentrations agreed quantitatively with the observations, whereas aerosol $\mathrm{SO}_{4}^{2-}$ was underestimated by $30 \%$. Considering this discrepancy, however, the main finding that dry deposition of $\mathrm{SO}_{2}$ is predominant, especially near source regions, would be unchanged.

In Fig. 3, high deposition, and thus surface concentrations too, of $\mathrm{SO}_{2}$ were observed very close to the large emission sources. Due to the activity of the Miyakejima Volcano, peaks of sulfur concentrations were observed near this area $\left(139.53^{\circ} \mathrm{E}, 34.081^{\circ} \mathrm{N}\right)$. Among the four seasons, $\mathrm{SO}_{2}$ concentrations were lower in the summer due to fast photochemical conversion of $\mathrm{SO}_{2}$ to sulfate and precipitation scavenging due to the high temperatures, large solar radiations, and high cloud activities. Cloud activities influence the heterogeneous production of sulfate because the conversion from $\mathrm{SO}_{2}$ to sulfate takes place efficiently in cloud and rain droplets. As a result, $\mathrm{SO}_{2}$ concentrations in the southern part of China were very low in July (not significant in deposition fields). Turbulent mixing affects surface concentrations in large emission source regions, substantially. During the daytime, when the mixing layer is developed, air pollutants are transported upward and the concentration within the layer becomes lower. The mixing layer height becomes larger in the summer and smaller in the winter over the inland regions due to surface heating and subsequent buoyancy effects. The effect is seen in the dry deposition field (Fig. 3b-d).

The $\mathrm{SO}_{2}$ concentration is largest in winter over the northern part of China and its downstream regions because $\mathrm{SO}_{2}$ emissions are highest in the winter due to the high coal consumption for domestic heating (Streets et al., 2003). However, this effect is not included in the simulations as our emission inventory only estimated the annual mean. The emission seasonality will certainly alter the deposition amounts 

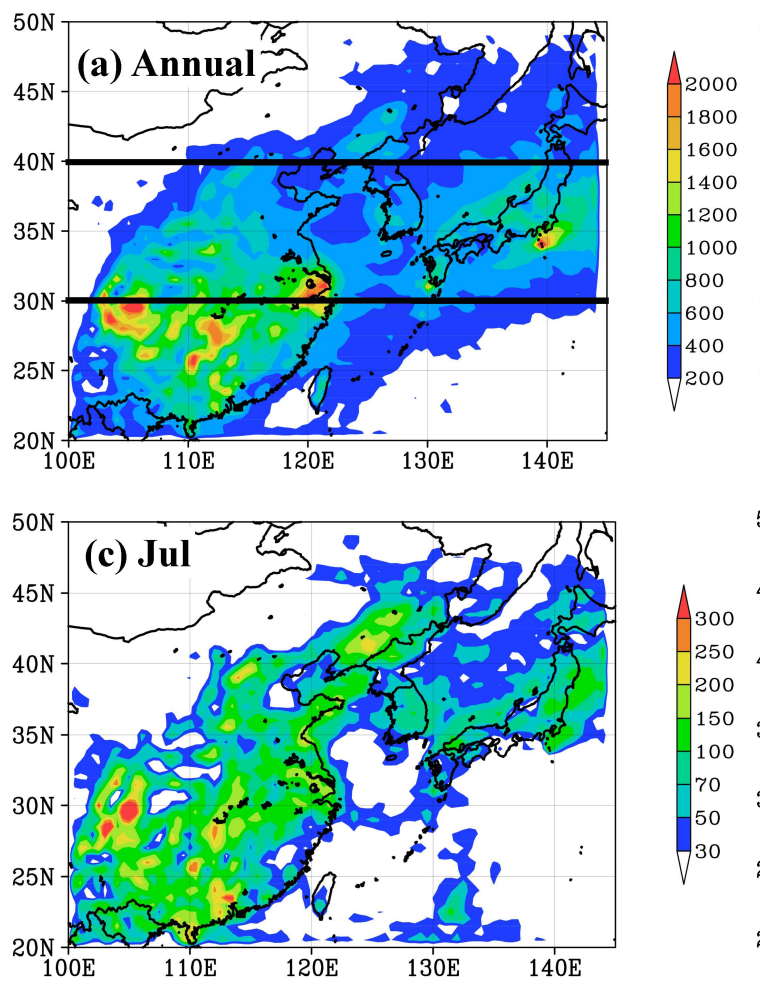
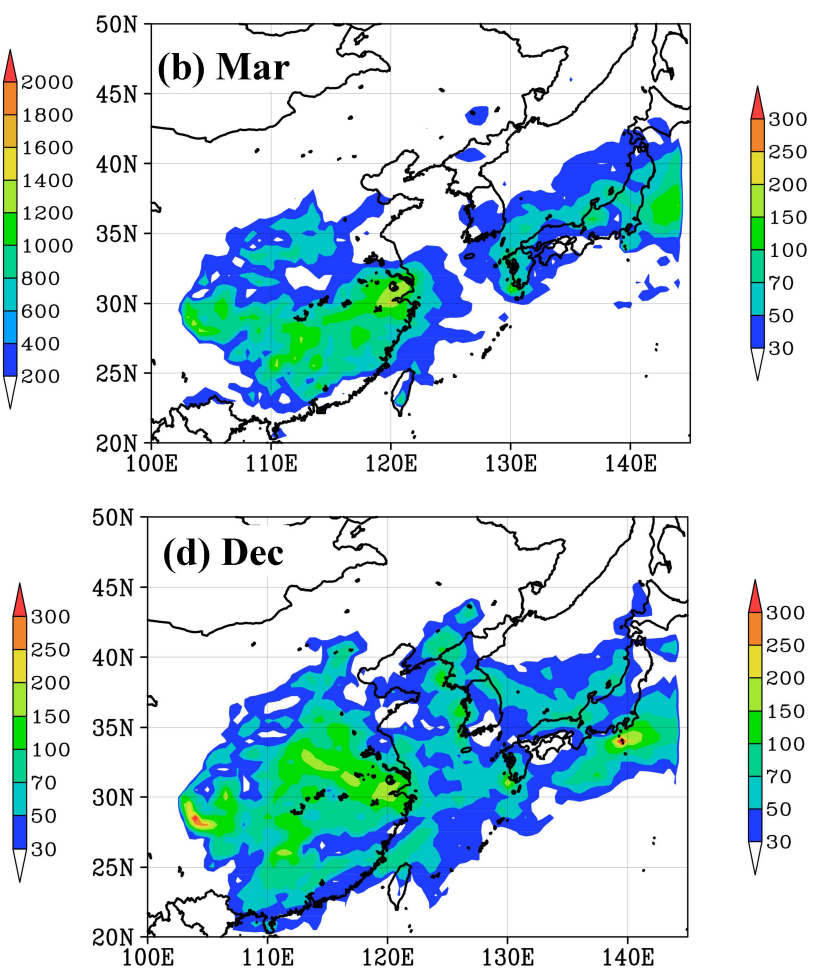

Fig. 4. Same as Fig. 3 but for the wet deposition of total $\mathrm{S}\left(\mathrm{mg} \mathrm{S} \mathrm{m}^{-2}\right)$.

and the source-receptor relationship. The effect could be estimated from this simulation's results because it is almost linear due to the simple atmospheric reactions for sulfur compounds (i.e., when the emissions of one region are uniformly two times greater, the effects from the region on deposition in other regions can be estimated as about two times greater as well). The volcanic eruptions from Miyakejima have substantially decreased in recent years and are about 1000 tons per day, 10 times smaller than those in 2002 (August, 2009; recent monitoring data provided by Dr. Kazahaya using the same method as in Kazahaya et al., 2001) and almost of the same order as other volcanoes in East Asia. The effect of this rapid change in volcanic emissions can also be roughly estimated in the SRR analysis in the same manner as the seasonal variations of emissions were assessed.

Figure 4 illustrates the (a) annual and (b-d) monthly accumulated wet deposition of total $\mathrm{S}$ in $\mathrm{mg} \mathrm{S} \mathrm{m}^{-2}$. The wet deposition of $\mathrm{S}$ includes both $\mathrm{SO}_{2}$ dissolved into cloud and rainwater droplets and aerosol $\mathrm{SO}_{4}^{2-}$ activated as cloud condensation nuclei $(\mathrm{CCN})$ and scavenged by rainwater. Both are measured as the $\mathrm{SO}_{4}^{2-}$ ion in the EANET rainwater monitoring samples. The wet deposition amounts appear to be smaller than the dry deposition amounts over the northeastern Asian region. However, as the modeled $\mathrm{SO}_{4}^{2-}$ wet deposition was found to be underestimated, as discussed in Sect. 3, the wet deposition amounts could be comparable to the dry deposition amounts.
Wet deposition depends not only on surface concentrations but also on the concentrations in the entire column up to the cloud top and the water droplet mixing ratios. Wet deposition was larger in the polluted and heavy precipitation regions. The large amount of wet deposition of $\mathrm{SO}_{4}^{2-}$ over the southern part of China in summer was related to cumulus precipitation. As precipitation was larger in summer over northern parts of the Asian continent, the amount of wet deposition was larger in summer. Substantial amounts of deposition are found over the ocean for the wet deposition field (Fig. 4a), whereas the amount of dry depositions is relatively smaller over the ocean (Fig. 3a).

\subsection{Total sulfur deposition and the source-receptor relationship}

The annually accumulated SRRs of sulfur compounds are listed in Table 4. The upper part of Table 4 indicates the amounts of annually accumulated dry and wet deposition of sulfur at each receptor region (left panel of Fig. 1) and the oceanic receptor regions (right panel of Fig. 1) in 2002. Because the sizes of the regions differ, the deposition unit is given in $\mathrm{mg} \mathrm{m}^{-2} \mathrm{yr}^{-1}$, too. The unit is consistent with that in Figs. 3 and 4. In the lower part of Table 4, the annual contributions of sources (rows) of total $\mathrm{S}\left(\mathrm{SO}_{2}\right.$ plus $\mathrm{SO}_{4}^{2-}$ ) deposition to land and ocean receptor regions (columns) are given. The impacts of $\mathrm{SO}_{\mathrm{x}}$ emissions from one source region 
Table 4. Annual deposition ( $\mathrm{kton} \mathrm{S} \mathrm{yr}^{-1}$ and $\mathrm{mg} \mathrm{S} \mathrm{m}^{-2} \mathrm{yr}^{-1}$ ) of sulfur and contributions of source regions to receptor regions (\%) in 2002.

\begin{tabular}{|c|c|c|c|c|c|c|c|c|}
\hline \multicolumn{9}{|c|}{ Annual deposition of sulfur (unit: kton $\mathrm{S} \mathrm{yr}^{-1}$ ) } \\
\hline Region & I & II & III & IV & $\mathrm{V}$ & YEC & SJ & NWP \\
\hline Dry & 294.1 & 1863.9 & 989.6 & 161.1 & 392.1 & 75.9 & 57.8 & 135.1 \\
\hline Wet & 329.3 & 1295.8 & $1,567.3$ & 112.1 & 822.8 & 157.7 & 279.7 & 375.5 \\
\hline Total & 623.5 & 3159.7 & 2557.0 & 273.2 & 1214.9 & 233.5 & 337.5 & 510.5 \\
\hline \multicolumn{9}{|c|}{ Annual deposition of sulfur per regional area (unit: $\mathrm{mg} \mathrm{S} \mathrm{m}^{-2} \mathrm{yr}^{-1}$ ) } \\
\hline Total & 356.0 & 1330.7 & 1093.3 & 1167.3 & 651.9 & 201.8 & 395.5 & 163.9 \\
\hline \multicolumn{9}{|c|}{ Annual mean contribution of sources to receptors for sulfur deposition (\%) } \\
\hline $\mathrm{S} / \mathrm{R}$ & I & II & III & IV & $\mathrm{V}$ & YEC & SJ & NWP \\
\hline I & 53 & 2 & 1 & 4 & 3 & 6 & 16 & 3 \\
\hline II & 43 & 83 & 14 & 18 & 19 & 53 & 40 & 24 \\
\hline III & 2 & 14 & 84 & 6 & 8 & 23 & 5 & 14 \\
\hline IV & 2 & 1 & 0 & 66 & 5 & 10 & 16 & 5 \\
\hline V & 1 & 0 & 1 & 6 & 65 & 7 & 23 & 54 \\
\hline
\end{tabular}

to total $\mathrm{S}$ deposition in the receptor regions are described. As described before, Regions I, II, III, IV, and V indicate North China (north of $40^{\circ} \mathrm{N}$ ), Central China (between 40 and $30^{\circ} \mathrm{N}$ ), South China (south of $30^{\circ} \mathrm{N}$ ), South Korea, and Japan, respectively.

The annual deposition of sulfur was large in Regions II and III (3160 and $2560 \mathrm{kton} \mathrm{S} \mathrm{yr}^{-1}$, respectively), where $\mathrm{SO}_{\mathrm{x}}$ emissions were large as well (6020 and $3300 \mathrm{kton} \mathrm{S} \mathrm{yr}^{-1}$, respectively). The deposition of $\mathrm{S}$ in Regions II and III accounted for about $50 \%$ and $75 \%$ of the emissions of S, respectively. Dry deposition was larger in Region II, whereas wet deposition was predominant in Region III. The self contribution (defined as contribution of one source region to the same receptor region) for SRR in Regions II and III were the largest among the 5 regions (83\% and $84 \%$, respectively), and the second largest contributions to each were from each other's region (14\%). Thus, the two regions exchanged sulfur with each other (together accounting for $97 \%$ for Region II and $98 \%$ for Region III), mainly via dry deposition to Region II and wet deposition to Region III. The contributions to Regions II and III from the other regions (I, IV, and V) were smaller than $2 \%$.

The deposition of $\mathrm{S}$ in Region I (623 kton S) was about $60 \%$ of the emission amount in the region ( $1010 \mathrm{kton} S)$, but more than $40 \%$ of the $\mathrm{S}$ deposition was due to emissions from Region II. The contributions of dry and wet deposition were comparable in the region. The contributions from the other regions (III, IV, and V) were less than $2 \%$.

The deposition of $\mathrm{S}$ in Region IV (273 kton S) was about $50 \%$ of the emission amount in the region ( $558 \mathrm{kton} \mathrm{S})$, with the self contribution being the largest $(66 \%)$. The second largest contribution was due to emissions from Region II
(18\%). The contribution of dry deposition was somewhat larger than that of wet deposition. The contributions from the other regions (I, III and V) were not negligible (4, 6, and $6 \%$, respectively).

The deposition of S in Region V (1215 kton S) was about three times larger than the "anthropogenic emissions" from the region ( $455 \mathrm{kton} \mathrm{S}$ ) and was equal to $56 \%$ of the total emissions (i.e., anthropogenic and the Miyake volcanic emissions, $2188.8 \mathrm{kton} \mathrm{S}$ ). The self contribution was $65 \%$, and the second largest contribution was due to Region II (19\%). Although a substantial amount of the deposition was from emissions from the Miyakejima volcano in Region $\mathrm{V}$, the contribution of Region II to Region V was as large as that to Region IV. Because the Miyakejima Volcano is located in the east of Japan, most of its volcanic sulfur was transported eastward due to westerlies and northwesterlies, except in summer when the Pacific High is predominant and the volcanic plume was transported west to southwestward (Kajino et al., 2004). As a result, the largest contributor to the Northwest Pacific Region (NWP) was Region V (54\%).

\subsection{Total sulfur deposition to the ocean and the contributions of the source regions}

Total S deposition to the ocean was assessed in this section. The amounts of total sulfur deposition to the Yellow Sea and the East China Sea (YEC), the Sea of Japan (SJ), and the Northwest Pacific Ocean (NWP) were 230, 340, and 510 kton S, respectively, which were comparable to or somewhat smaller than deposition amounts over the land receptor regions. It should be noted that the receptor regions and the oceanic regions are not completely separated, and they 
sometimes overlap. Wet deposition was more predominant than dry deposition over all of the ocean regions. The largest contributor to YEC was Region II (53\%), and the second and third largest were Region III (23\%) and Region IV (10\%). The largest contributor to SJ was also Region II (40\%), and the second largest was Region V ( $23 \%)$, with Regions I and IV $(16 \%)$ next in contribution size. As discussed before, the largest contributor to NWP was Region V, which accounted for $54 \%$ of the total deposition over the region, mostly of Miyake volcanic origin. The second and third largest were Region II (24\%) and Region III (14\%).

It is difficult to evaluate the contributions of sulfur, which is not calculated in the model, such as $\mathrm{SO}_{2}$ from shipping and biogenic $\mathrm{S}$ from ocean surfaces. $\mathrm{SO}_{2}$ from international shipping accounted for only $5 \%$ of that from the three Northeast Asian countries (Streets et al., 2003) and that from biogenic dimethyl sulfide (DMS) accounted for less than $5 \%$ of that from the countries and the Miyakejima volcano (Kajino et al., 2004). However, as far as deposition over ocean is concerned, contributions of those $\mathrm{S}$ could be substantial.

\subsection{Spatial distributions of total sulfur deposition and the source-receptor relationship and its seasonal variation}

Figures 5 to 9 illustrate the horizontal distributions of (a) annual and (b-d) monthly mean contributions of the respective source regions (I to V) to total S deposition (\%). The horizontal features are very different than those in the SRR table. They give additional information on SRRs, such as true contributions for specific small subregional areas. Area averages of each receptor region and each oceanic region correspond to the values in Table 4. The solid lines in Figs. 5a, 6a, 7a, 8a, and $9 \mathrm{a}$ indicate $40^{\circ} \mathrm{N}$ and $30^{\circ} \mathrm{N}$, the border between Regions I and II and that between Regions II and III, respectively.

Region I contributed only a few percent as a source to other receptor regions (Fig. 5). Though the regional average of the contributions from Region I to Regions IV and V are less than 5\%, the Region I contributions exceeded $10 \%$ in the northern part of Regions IV and V (Fig. 5a). As the wind pattern and precipitation vary substantially by season in northeast Asia, the SRRs vary accordingly. Figure 5 shows that the contributions from sources from Region I were similar in March and December, and the values were about 5 to $20 \%$ in the northern part of South Korea, the coastal regions of Japan's main island facing the Sea of Japan, and Hokkaido Island. The contribution in July over the area south of $40^{\circ} \mathrm{N}$ was smaller than $5 \%$ due to the Pacific High, and the amount of wet deposition was substantial.

Region II was the most influential source to all regions due to its large emissions and its location under the strong influences of mid-latitude disturbances and mid-latitude westerlies (Fig. 6). The contribution of Regions II to every other region (outside of Region II) exceeded $14 \%$. It was smaller than $20 \%$ in Regions III, IV, and V. The regionally averaged contribution from Region II to Region I was $43 \%$ (Table 4), with a maximum larger than $60 \%$ near the border (Fig. 6a). Region V included large areas of ocean surface. The overall regionally averaged contribution from Region II to Region $\mathrm{V}$ was $19 \%$. The contribution over the coastal regions of the southwestern islands of the Japan archipelago exceeded $30 \%$, and that over coastal regions of the main island facing the Sea of Japan was about 20 to $30 \%$. Seasonal variations of the contribution from this major contributor region, Region II, to the receptor regions were not very clear in the spatial distribution. A clear seasonal change was found over the ocean, especially for SJ. The contribution to the northern part of SJ was large in terms of its annual mean, spring, and summer $(>60 \%)$. In winter, however, the northerly monsoon due to the Siberian High prevented the transport of air pollutants from Region II northward.

Region III was the second major contributing source region for trans-regional transport, but the contributions were not very large, generally smaller than $10 \%$ to the other regions, such as I, IV, and V (Fig. 7). The southern part of Region III is under the influence of the trade wind zone, and the contribution to eastern regions may not be large. Averaged over the year, the contributions of Region III to North China, South Korea, and the Japanese main islands were small, but the contribution was as large as $20-25 \%$ over the southwestern islands of the Japan archipelago (Fig. 7a). The contributions to Regions I, IV, and V were small throughout the year, but in spring, as the mid-latitude disturbances moved eastwards with air pollutants, the contribution to the western part of Japan was high (10-30\%, Fig. 7b).

The contribution of Region IV to other regions was smaller than $2 \%$, except for Region $\mathrm{V}$, in which it was $5 \%$ on average (Table 4). Figure 8a shows that the deposition in Region V occurred mainly over the Sea of Japan and not over the inland area of Region V. The contribution of Region IV was largest in July. It amounted to 5-10\% in the eastern parts of Region I and 5-15\% in the northern part of Japan. The contribution to SJ was large in July.

The contribution of Region V to other regions was small $(0-1 \%$ for Regions I, II, and III, and $6 \%$ for Region IV) on average (Table 4) as well as in its horizontal distribution $(<5 \%$ across other regions, Fig. 9a). In summer, however, under the influence of the Pacific High, the contribution was $5-15 \%$ over some parts of Region I, $5 \%$ of Region IV, and $10-25 \%$ over the northern part of Taiwan and some parts of Region III.

Atmospheric deposition to the ocean varied substantially by subregion and by season. The largest depositions were found over the Yellow Sea, the north of the East China Sea, and the south of the Sea of Japan (Figs. 3a and 4a). The area-averaged contribution of Region I to YEC was only $6 \%$ (Table 4) but the contributions to the Bo Hai Sea (north of the Yellow Sea) and the Yellow Sea was largest in winter, accounting for $20-30 \%$ due to the prevailing northerly seasonal wind (Fig. 5a and d). The contribution of Region I to 

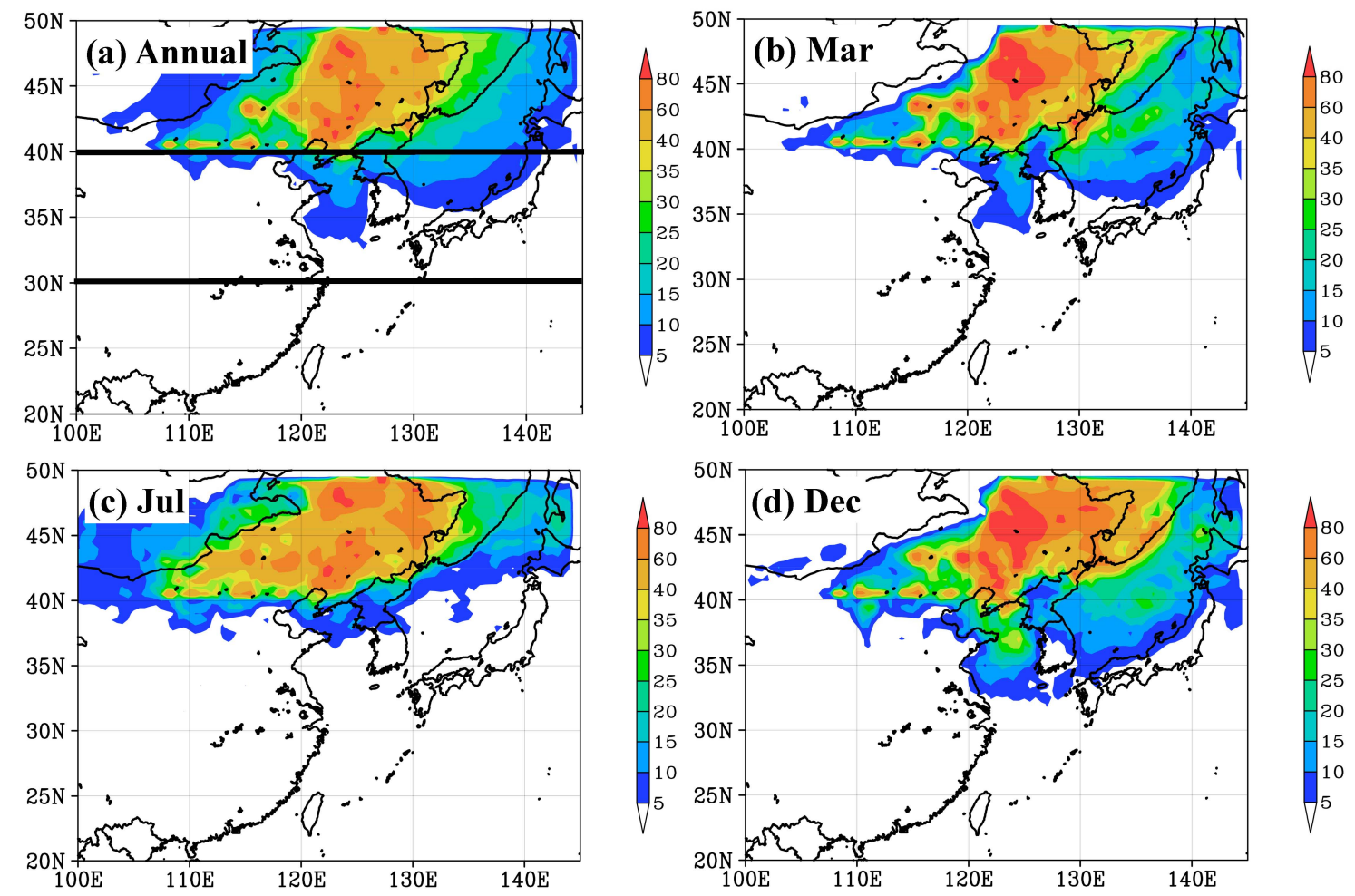

Fig. 5. Spatial distributions of (a) annual mean contributions of Source Region I to total sulfur deposition and monthly mean values for (b) March, (c) July, and (d) December (\%). The solid lines in (a) indicate $40^{\circ} \mathrm{N}$ and $30^{\circ} \mathrm{N}$, the borders between Regions I and II and between Regions II and III, respectively.

SJ was $16 \%$ on average (Table 4 ), whereas it accounted for up to $30 \%$ in the northern part of SJ (Fig. 5a). It varied by season and was 10-25\% in March and December, whereas it was smaller than $5 \%$ over the area south of $40^{\circ} \mathrm{N}$ of SJ in July due to the influence of the Pacific High. The mean contribution of Region II to YEC was $53 \%$ (Table 4); it was larger than $40 \%$ in most areas of YEC and $60-80 \%$ over the Bo Hai Sea (Fig. 6). The contribution of Region II to SJ was $40 \%$ on average (Table 4 ) and was mostly deposited over the northern part ( $>40 \%)$, except in winter due to the above-mentioned influence of the Siberian High (Fig. 6). Region III contributed, on average, $23 \%$ and $14 \%$ to YEC and NWP, respectively (Table 4). The contribution was larger in the southern part of YEC, especially near the coastal region, and accounted for 10-30\% of deposition over the southern part of the Yellow Sea and 20-40\% over the East China Sea (Fig. 7). The contribution to NWP was smallest in summer because the Pacific High prevented the transport of air pollutants from Region III eastward (Fig. 7c). Region IV contributed $16 \%$ and $10 \%$ of the deposition over SJ and YEC, respectively (Table 4$)$. The contribution was largest in the eastern part of the Yellow Sea (5-20\%) and the western part of SJ (5-25\%). The contribution over SJ was highest in the summer (15-40\%, Fig. 8c) because the Pacific High prevented airflow from the Asian continent. The contribution of Region V to NWP and SJ was $54 \%$ and $23 \%$, respectively (Table 4). Figure 9a shows the contribution of Region $\mathrm{V}$, especially that of Miyake volcanic origin, was larger over NWP (up to $80 \%$ ) and SJ near the coastal region of the Japan Archipelago (35-60\%). Figure 9b-d shows the contribution to SJ was $20-30 \%$ in the eastern part in March, 10-60\% over the whole region in July, and 5-30\% near the coast in December. The contribution to YEC was largest in July, accounting for $5-35 \%$ in the eastern and southern parts of the ocean area (Fig. 9c).

Because seasonal variation of anthropogenic species was not provided in our emission inventory, we didn't use it for the SRR calculations. Even though nonlinearity effect is less significant for sulfur chemistry as discussed in Sect. 4.2, some nonlinearity effect may exist, e.g. higher emission during winter lead to slower conversion rate from S(IV) to S(VI), resulting in non-linear changes in the SRR. Still, as the most contributing sectors for Asian $\mathrm{SO}_{2}$ emission were industry and power generation, which accounted for about $80 \%$ of the total $\mathrm{SO}_{2}$, the seasonal variation was not very substantial $\left(\mathrm{SO}_{2}\right.$ in winter is only $25 \%$ larger than that in summer; Streets et al., 2003). Thus, the seasonal variation in $\mathrm{SO}_{2}$ emission will not cause highly non-linear impacts on the SRR of sulfur in this simulation. Under the LTP project, we are now heading to investigate SRR of other reactive and 

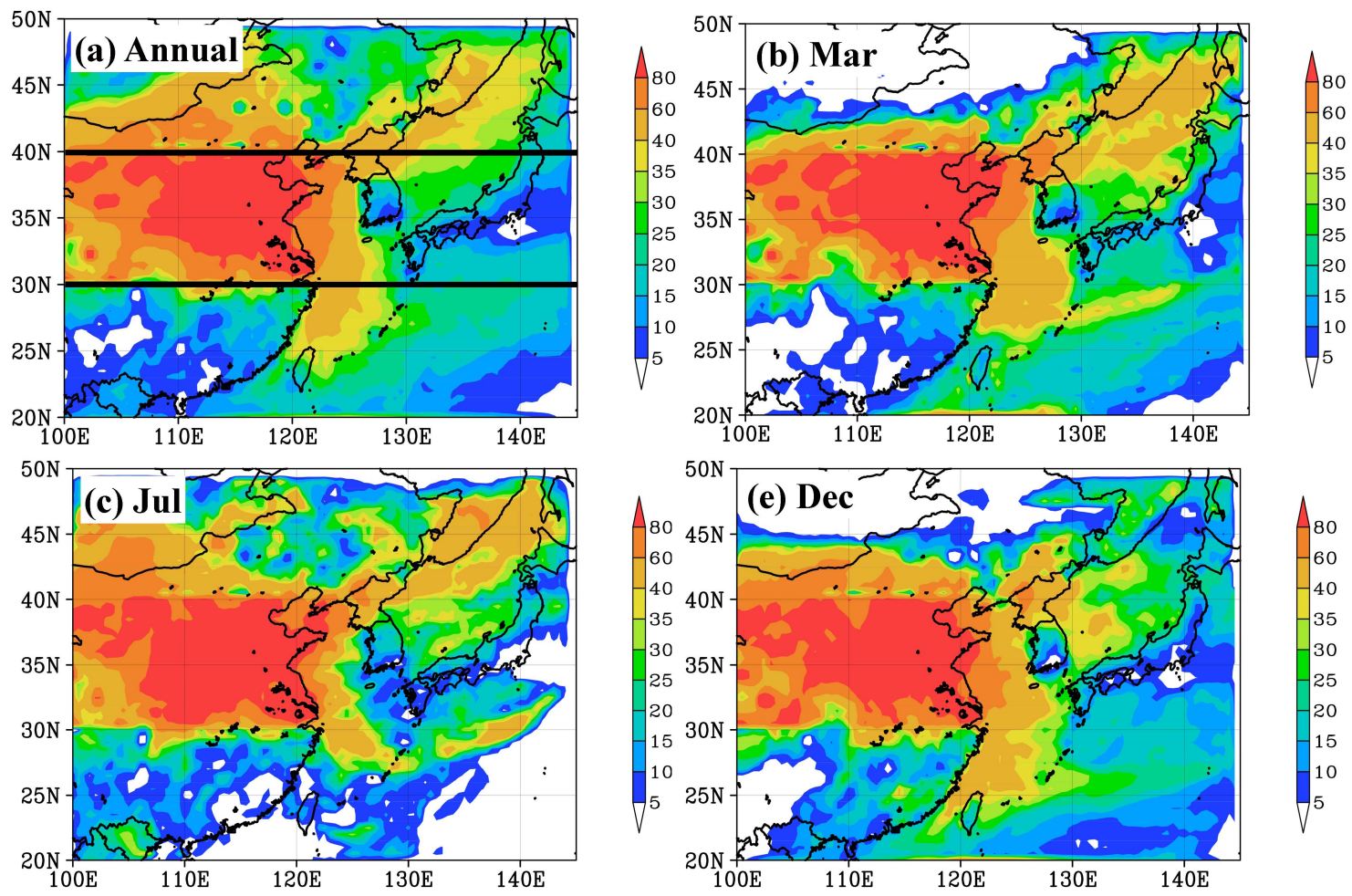

Fig. 6. Same as Fig. 5 but for Source region II.
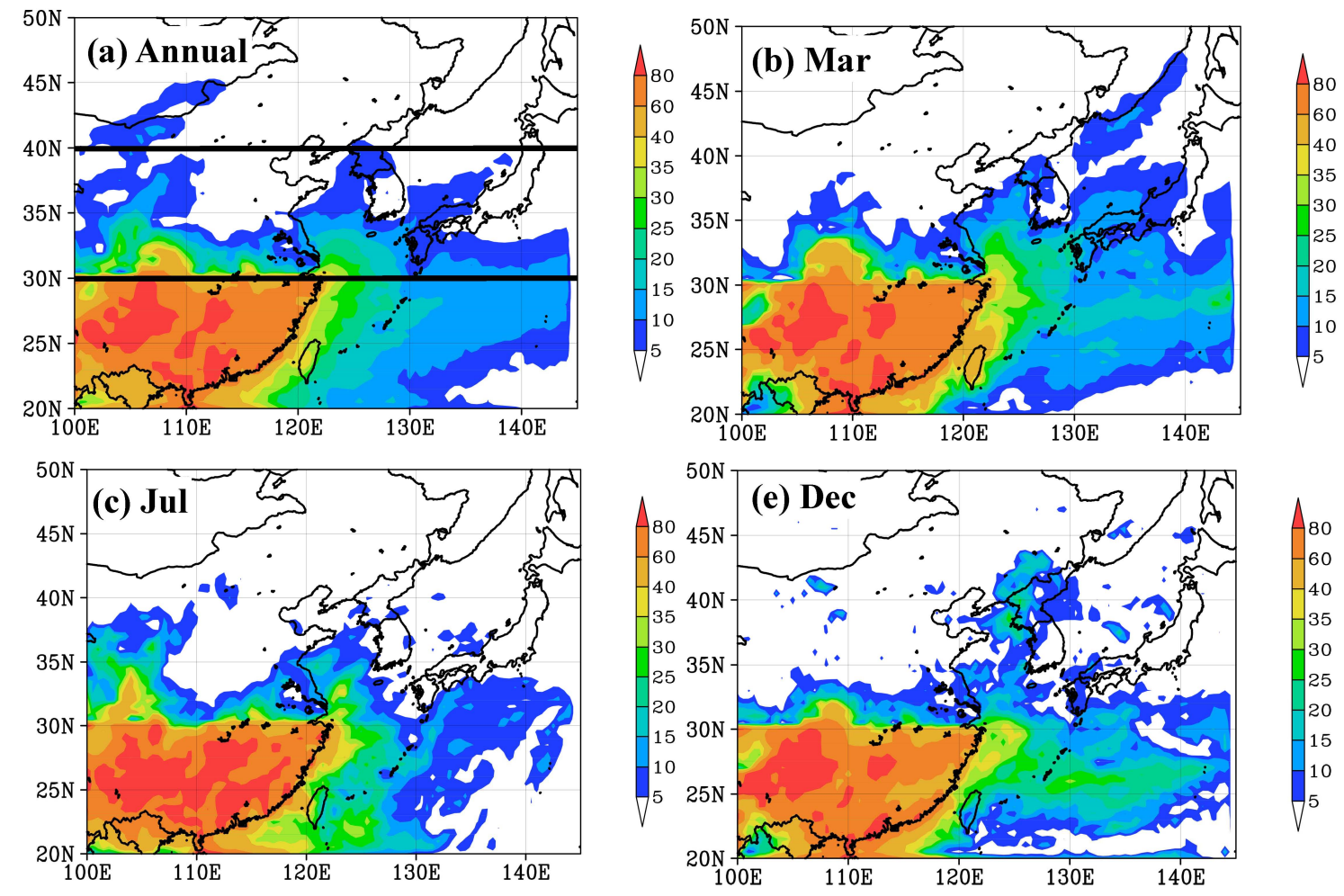

Fig. 7. Same as Fig. 5 but for Source region III. 

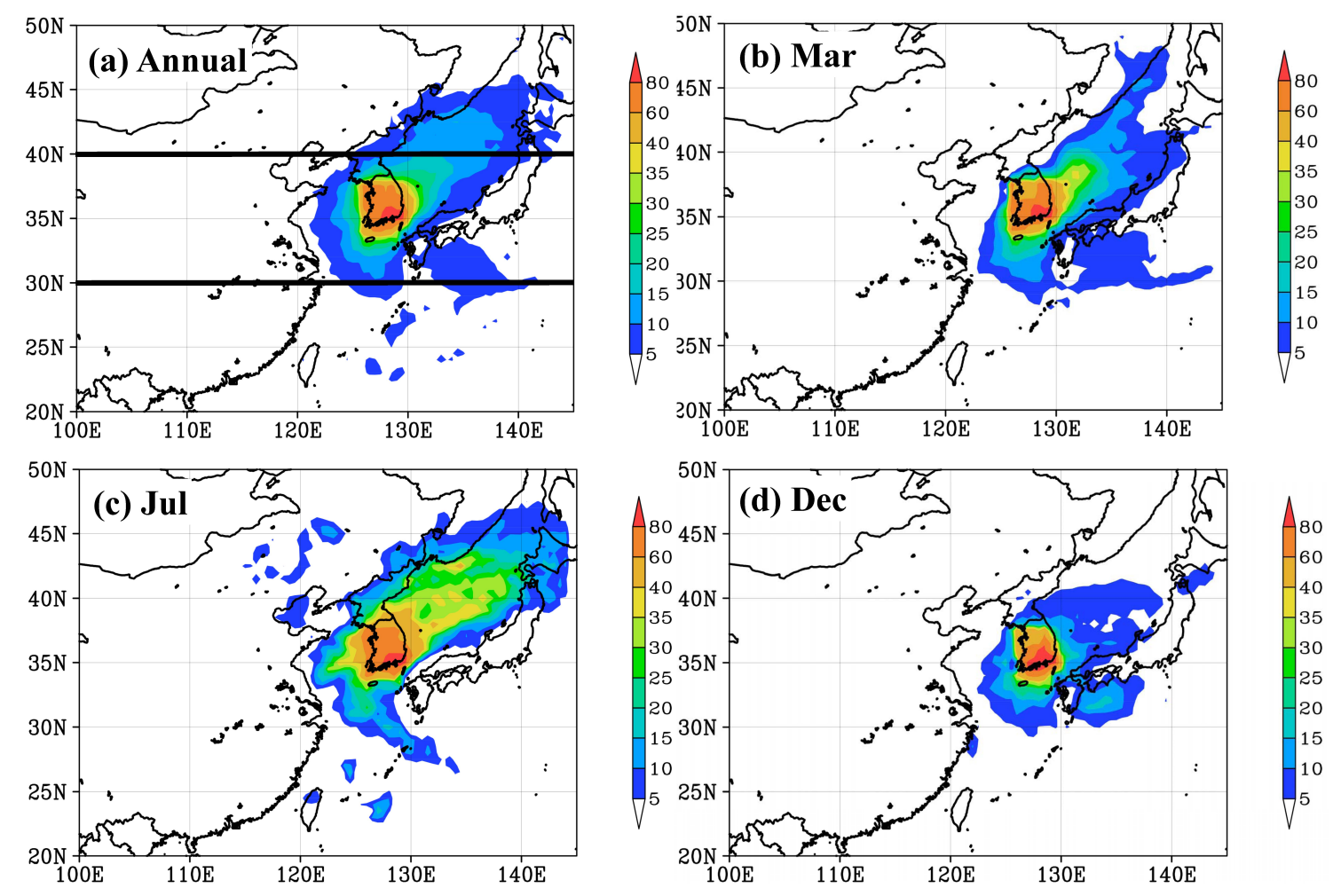

Fig. 8. Same as Fig. 5 but for Source region IV.
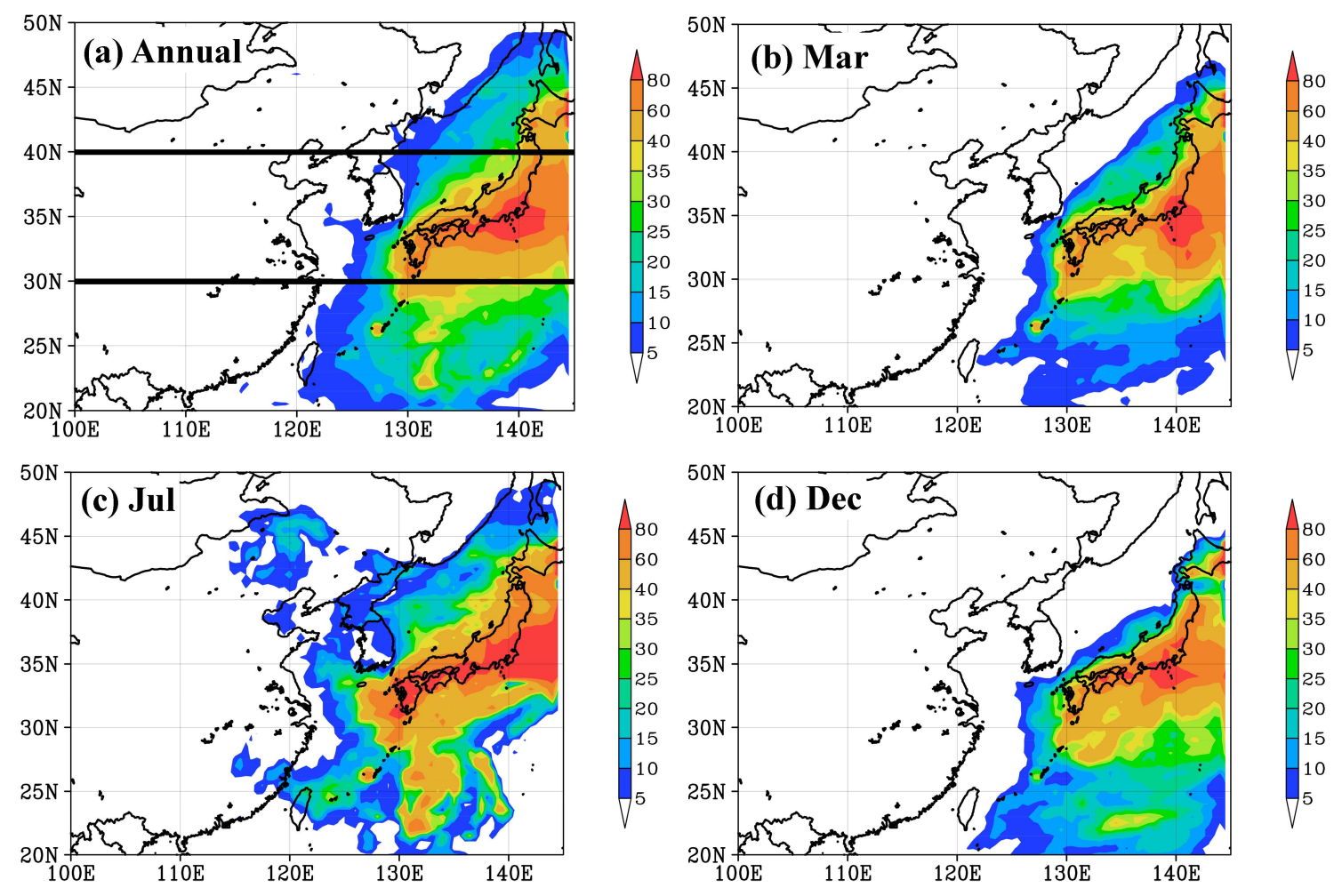

Fig. 9. Same as Fig. 5 but for Source region V. 
highly nonlinear components such as nitrogen compounds, $\mathrm{O}_{3}$ and PMs among the Northeast Asian countries, by following the EMEP modeling works (Nyiri et al., 2010). In this case, it is indispensiblae to implement temporal variations in emission fluxes and to utilize 15 or $20 \%$ reduction method instead of full reduction for the accurate assessment of SRR for those reactive components.

\section{Conclusions}

Spatial distributions of the source-receptor relationships (SRRs) of sulfur over northeast Asia were examined using a chemical transport model, Regional Air Quality Model (RAQM). RAQM was driven by the meteorological fields predicted using the Mesoscale Meteorological Model (MM5). The RAQM model was developed at the Asia Center for Air Pollution Research (ACAP), formerly the Acid Deposition and Oxidant Research Center (ADORC). The emission inventory used in this study was developed by the Longrange Trans-boundary Air Pollutants in Northeast Asia (LTP project) of Tripartite Environment Ministers Meeting among Japan, China and Korea (TEMM).

The simulation was conducted for the entire year of 2002. Simulation results were evaluated using monitoring data from six remote stations of the Acid Deposition Monitoring Network in East Asia (EANET). The modeled $\mathrm{SO}_{2}$ and $\mathrm{O}_{3}$ concentrations agreed well with observations quantitatively. The modeled aerosol $\mathrm{SO}_{4}^{2-}$ was underestimated by $30 \%$, but the correlation coefficient was large $(R=0.80)$. The modeled wet deposition flux of $\mathrm{SO}_{4}^{2-}$ was generally underestimated by about $50 \%$, with some exceptions of overestimation.

The domain was divided into five source-receptor regions: I, North China; II, Central China; III, South China; IV, South Korea; and V, Japan. The deposition over the oceanic regions was also assessed and the oceanic areas were divided into three regions: YEC, the Yellow Sea and East China Sea; SJ, the Sea of Japan; and NWP, the Northwest Pacific Ocean.

The sulfur deposition in each receptor region amounted to about $50-75 \%$ of the emissions from the same region. Dry deposition dominated over wet deposition in Regions II and IV, whereas wet deposition dominated in Regions I, III, and $\mathrm{V}$, and all of the ocean regions. The largest contribution to the deposition in each region was originated from the same region, accounting for 53-84\% of deposition. The second largest contribution was due to Region II, accounting for 14$43 \%$, outside Region II itself. The second largest contribution to Region II was Region III. Thus, the two regions exchanged sulfur with each other, mainly via dry deposition to Region II and wet deposition to Region III. The largest contributions to YEC and SJ were from Region II (53\% and $40 \%$, respectively), whereas that to NWP was from Region V (54\%), which was mostly of Miyakejima volcanic origin. The second largest contribution to YEC was Region III
(23\%), that to SJ was Region V (23\%), and that to NWP was Region II (24\%).

The horizontal distribution of SRRs revealed that subregional values varied about a factor of two from the regionally averaged values. This variation was due to nonuniformity of the deposition field. It was found to be important to examine the spatial distribution fields to identify subregional areas where deposition was highest within a region. The horizontal distribution changed substantially by season. Deposition and SRR features in summer were different than those in spring and winter, due to larger precipitation and different wind patterns in summer. Westerly to northwesterly winds prevailed over the northeast Asian regions throughout the year, except in summer when southerly to southeasterly winds prevailed under the influence of the Pacific High.

Acknowledgements. This research was promoted by the joint research on Long-range Trans-boundary Air Pollutants in Northeast Asia (LTP project) and Tripartite Environment Ministers Meeting among Japan, China and Korea (TEMM). This research was supported by the Environment Research and Technology Development Fund (Project No. B-0905) of the Ministry of the Environment, Japan and the Grant-in-Aid for JSPS Fellows (Project No. 07J01611) of Japan Society for the Promotion of Science (JSPS).

Edited by: E. Vignati

\section{References}

An, J., Ueda, H., Wang, Z., Matsuda, K., Kajino, M., and Cheng, X.: Simulations of monthly mean nitrate concentrations in precipitation, Atmos. Environ., 36, 4159-4171, 2002.

An, J., Ueda, H., Matsuda, K. Hasome, H., and Iwata, M.: Simulated impacts of $\mathrm{SO}_{2}$ emissions from the Miyake volcano on concentration and deposition of sulfur oxides in September and October of 2000, Atmos. Environ., 37, 3039-3046, 2003.

Atkinson, R., Lloyd, A. C., and Winges, D.: An updated chemical mechanism for hydrocarbon/ $\mathrm{NOx} / \mathrm{SO}_{2}$ photooxidations suitable for inclusion in atmospheric simulation models, Atmos. Environ., 16, 1341-1355, 1982.

Betts, A. K.: A new convective adjustment scheme. Part I: Observational and theoretical basis, Q. J. Roy. Meteorol. Soc., 112, 677-692, 1986.

Betts, A. K. and Miller, M. J.: A new convective adjustment scheme. Part II: Single column tests using GATE wave, BOMEX, ATEX and Arctic air-mass data sets, Q. J. Roy. Meteorol. Soc., 112, 693-709, 1986.

Byun, D. W. and Dennis, R.: Design artifacts in Eulerian air quality models: Evaluation of the effects of layer thickness and vertical profile correction on surface ozone concentrations, Atmos. Environ. 29, 105-126, 1995.

Carmichael, G. R., Peters, L. K., and Saylor, R. D.: The STEM-II regional scale acid deposition and photochemical oxidant model: I. An overview of model development and applications, Atmos. Environ., 25, 2077-2092, 1991. 
Carmichael, G. R., Uno I., Phadnis, M. J., Zhang, Y., and Young, S. W.: Tropospheric ozone production and transport in spring time in East Asia, J. Geophys. Res., 103, 10649-10671, 1998.

Carmichael, G. R., Calori, G., Hayami, H., Uno, I., Cho, S. Y., Engardt, M., Kim, S.-B., Ichikawa, Y., Ikeda, Y., Woo, J.-H., Ueda, H., and Amann, M.: The MICS-Asia study: model intercomparison of long-range transport and sulfur deposition in East Asia, Atmos. Environ., 36, 175-199, 2002.

Carmichael, G. R., Sakurai T., Streets D., Hozumi Y., Ueda H., Park S. U., Fung C., Han Z., Kajino M., Engardt M., Bennet C., Hayami H., Sartelet K., Holloway T., Wang Z., Kannari A., Fu J., Matsuda K., Thongboonchoo N., and Amann, M.: MICS-Asia II: The Model Intercomparison Study for Asia Phase II Methodology and Overview of Findings, Atmos. Environ., Special Issue: MICS-ASIA II, 42, 3468-3490, 2008.

Chameides, W. L. and Stelson, A. W.: Aqueous-phase chemical processes in deliquescent sea-salt aerosols: a mechanism that couples the atmospheric cycles of S and sea salt, J. Geophys. Res., 97, D18, 20565-20580, 1992.

Chang, J. S., Brost, R. A., Isaksen, I. S. A., Madronich, S., Middleton, P., Stockwell, W. R., and Walcek, C. J.: A three-dimensional Eulerian acid deposition model: Physical concepts and formulation, J. Geophys. Res., 92, 14681-14700, 1987.

Choi, K.-D., Kim, J.-S., and Kim, B.-G.: Annual Report for the 1st year's Joint Research on Long-Range Transboundary Air Pollutants in Northeast Asia, Secretariat of Working Group for LTP Project, NIER, Korea, 121 pp., 2001.

DeFries, R. S. and Townshend, J. R. G: NDVI-derived land cover classification at global scales, Int. J. Remote Sens., 15, 35673586, 1994.

Gery, M. W., Whitten, G. Z., Killus, J. P., and Dodge, M. C.: A photochemical kinetics mechanism for urban and regional scale computer modeling, J. Geophys. Res., 94, 12925-12956, 1989.

Grell, G. A., Dudhia, J., and Stauffer, D. R.: Description of the Fifth Generation Penn state/NCAR Meso-scale Model (MM5), NCAR Technical Note, NCAR/Tn-398+STR, CO, USA, 1994.

Han, Z.: A regional air quality model: Evaluation and simulation of $\mathrm{O}_{3}$ and relevant gaseous species in East Asia during spring 2001, Environ. Modell. Software, 22, 1328-1336, 2007.

Han, Z., Ueda, H., Matsuda, K., Zhang, R., Arao, K., Kanai, Y., and Hasome, H.: Model study on particle size segregation and deposition during Asian dust events in March 2002, J. Geophys. Res., 109, D19205, doi:10.1029/2004JD004920, 2004.

Han, Z., Ueda, H., and Matsuda, K.: Model study of the impact of biogenic emission on regional ozone and effectiveness of emission reduction scenarios over eastern China, Tellus 53B, 171191, 2005.

Han, Z., Ueda, H., and Sakurai, T.: Model study on acidifying wet deposition in East Asia during wintertime, Atmos. Environ., 40, 2360-2373, 2006.

Han, Z., Sakurai, T., Ueda, H., Carmichael, G. R., Streets, D., Hayam, H., Wang, Z., Holloway, H., Engardt, M., Hozumi, Y., Park, S. U., Kajino, M., Sartelet, K., Fung, C., Bennet, C., Thongboonchoo, N., Tang, Y., Chang, A., Matsuda, K., and Amann, M.: MICS-Asia II: Model intercomparison and evaluation of ozone and relevant species, Atmos. Environ., Special Issue: MICS-ASIA II, 42, 3491-3509, 2008.

He, D. and Huang, M.: A numerical study on tropospheric ozone over China, Atmos. Environ., 30, 2449-2451, 1996.
Hong, S.-Y. and Pan, H. L.: Nonlocal boundary layer vertical diffusion in a Medium-Range Forecast Model, Month. Weather Rev., 124, 2322-2339, 1996.

Hylland, K.: Polycyclic Aromatic Hydrocarbon (PAH) ecotoxicology in marine ecosystems, J. Toxicol. Environ. Health, Part A, 69, 109-123, 2006.

Kajino, M. Ueda, H., Satsumabayashi, H., and An, J.: Impacts of the eruption of Miyakejima Volcano on air quality over far east Asia, J. Geophys. Res., 109, D21204, doi:10.1029/2004JD004762, 2004.

Kajino, M. Ueda, H., Satsumabayashi, H., and Han, Z.: Increase in nitrate and chloride deposition in East Asia due to increased sulfate associated with the eruption of Miyakejima Volcano, J. Geophys. Res. 110, D18203, doi:10.1029/2005JD005879, 2005.

Kazahaya, K.: Volcanic gas study of the 2000 Miyakejima volcanic activity: degassing environment deduced from adhered gas component on ash and $\mathrm{SO}_{2}$ emission rate, J. Geogr., 110, 271-279, 2001 (in Japanese).

Kim, C.-H., Chang, L.-S., Kim, J.-S.., Meng, F., Kajino, M., Ueda, H., Zhang, Y., Son, H.-Y., He, Y., Xu, J., Sato, K., Song, C.K., Ban, S.-J., Sakurai, T., Han, Z., Duan, L., Lee, S.-J., Shim, S.-G., Young, S., and Lee, T.-Y.: Long-term simulations of the sulfur concentrations over the China, Japan and Korea: A model comparison study, Asia-Pac. J. Atmos. Sci., in press, 2011.

Lin, M., Oki, T., Bengtsson, M., Kanae, S., Holloway, T., and Streets, D. G.: Long-range transport of acidifying substances in East Asia - Part II Source-receptor relationships, Atmos. Environ., 42, 5956-5967, 2008.

Livingstone, D. R.: The fate of organic xenobiotics in aquatic ecosystems: quantitative and qualitative differences in biotransformation by invertebrates and fish, Comp. Biochem. Physiol, 120, 43-49, 1998.

Luo, C., John, J. C. St., Zhou, X. J., Lam, K. S., Wang, T., and Chameides, W. L.: A nonurban ozone air pollution episode over eastern China: Observations and model simulations, J. Geophys. Res., 105, 1889-1908, 2000.

Madronich, S.: Photodissociation in the atmosphere, 1. Actinic flux and the effects of ground reflections and clouds, J. Geophys. Res., 92, 9740-9752, 1987.

Nagashima, T., Ohara, T., Sudo, K., and Akimoto, H.: The relative importance of various source regions on East Asian surface ozone, Atmos. Chem. Phys., 10, 11305-11322, doi:10.5194/acp10-11305-2010, 2010.

Nenes, A., Pandis, S. N., and Pilinis, C.: ISORROPIA: A new thermodynamic equilibrium mode for multiphase multicomponent inorganic aerosols, Aquat. Geoch., 4, 123-152, 1998.

Nyiri, A., Gauss, M., and Klein, H.: Transboundary data by main pollutants $\left(\mathrm{S}, \mathrm{N}, \mathrm{O}_{3}\right)$ and $\mathrm{PM}$, Country reports $2010 \mathrm{MSC}-\mathrm{W}$ Data Note 1/2010, ISSN 1890-0003, 2010.

Ohara, T., Akimoto, H., Kurokawa, J., Horii, N., Yamaji, K., Yan, X., and Hayasaka, T.: An Asian emission inventory of anthropogenic emission sources for the period 1980-2020, Atmos. Chem. Phys., 7, 4419-4444, doi:10.5194/acp-7-4419-2007, 2007.

Satsumabayashi, H., Kawamura, M., Katsuno, T., Futaki, K., Murano, K., Carmichael, G. R., Kajino, M., and Ueda, H.: Effects of Miyake volcanic effluents on airborne particles and precipitation in Central Japan, J. Geophys. Res., 109, D19202, doi:10.1029/2003JD004204, 2004. 
Suzuki, N., Hayakawa, K., Kameda, T., Toriba, A., Tang, N., Tabata, M. J., Takada, K., Wada, S., Omori, K., Srivastav, A. K., Mishima, H., and Hattori, A.: Monohydroxylated polycyclic aromatic hydrocarbons inhibit both osteoclastic and osteoblastic activities in teleost scales, Life Sciences, 84, 482-488, 2009.

Streets, D. G., Bond, T. C., Carmichael, G. R., Fernandes, S. D., Fu, Q., He, D., Klimont, Z., Nelson, S. M., Tsai, N. Y., Wang M. Q., Woo, J.-H., and Yarber, K. F.: An inventory of gaseous and primary aerosol emissions in Asia in the year 2000, J. Geophys. Res., 108, D218809, doi:10.1029/2002JD003093, 2003.

Tang, Y., Carmichael, G. R., Kurata, G., Uno, I., Weber, R. J., Song, C. -H., Guttikunda, S. K., Woo, J-. H., Streets, D. G., Wei, C., Clarke, A. D., Huebert, B., and Anderson, T. L.: Impacts of dust on regional tropospheric chemistry during the ACE-Asia experiment: A model study with observations, J. Geophys. Res., 109, D19S21, doi:10.1029/2003JD003806, 2004.

Walcek, C. J. and Aleksic, N. M.: A simple but accurate mass conservative peak-preserving, mixing ratio bounded advection algorithm with Fortran code, Atmos. Environ., 32, 3863-3880, 1998.
Walcek, C. J., Brost, R. A., Chang, J. S., and Wesely, M. L.: $\mathrm{SO}_{2}$, sulfate and $\mathrm{HNO}_{3}$ deposition velocities computed using regional landuse and meteorological data, Atmos. Environ., 20, 949-964, 1986.

Walmsley, J. L. and Wesely, M. L.: Modifiction of coded parameterizations of surface resistances to gaseous dry deposition, Atmos. Environ., 30, 1181-1188, 1996.

Wang, Z., Xie, F., Sakurai T., Ueda H., Han, Z., Carmichael, G. R., Streets, D., Engardt, M., Holloway, T., Hayami, H., Kajino, M., Thongboonchoo, N., Bennet, C., Park, S. U., Fung, C., Chang, A., Sartelet, K., and Amann, M.: MICS-Asia II: Model Intercomparison and evaluation of acid deposition, Atmos. Environ., Special Issue: MICS-ASIA II, 42, 3528-3542, 2008.

Zhang, Q., Streets, D. G., Carmichael, G. R., He, K. B., Huo, H., Kannari, A., Klimont, Z., Park, I. S., Reddy, S., Fu, J. S., Chen, D., Duan, L., Lei, Y., Wang, L. T., and Yao, Z. L.: Asian emissions in 2006 for the NASA INTEX-B mission, Atmos. Chem. Phys., 9, 5131-5153, doi:10.5194/acp-9-5131-2009, 2009. 